\title{
No More "Us" and "Them": Integrating Recovery and Well-Being into a Conceptual Model for Mental Health Policy
}

[French translation: Pour qu'il n'y ait plus de « nous » et d' « eux » : un modèle conceptuel de politiques en matière de santé mentale qui intègre les concepts de rétablissement et de bien-être]

\author{
Gillian Mulvale \\ McMaster University \\ Mary Bartram \\ Carleton University
}

[La version française suit.]

\begin{abstract}
To set the stage for this special edition on Responses to the Mental Health Strategy for Canada: Canadian and International Perspectives on Mobilizing Change, we discuss the role of ideas in the public policy literature and the influence of key ideas over the history of mental health policy. Drawing on academic and policy literature and feedback from a convenience sample of mental health policy makers, we integrate the concepts of recovery and well-being into a conceptual model that can be used by policy makers as a tool to realize the transformative ideas captured in the Mental Health Strategy for Canada.
\end{abstract}

Keywords: mental health policy, ideas, recovery, well-being, integrated conceptual model, mental health systems transformation

Gillian Mulvale, Assistant Professor Health Policy and Management, DeGroote School of Business, McMaster University, Hamilton, Ontario; Mary Bartram, School of Public Policy and Administration, Carleton University, Ottawa, Ontario.

The authors would like to acknowledge Howard Chodos, Marie Fast, Mary Pat MacKinnon, Katherine Scott, Colleen Simms, Robert Simpson, Heather Stuart, and Patricia Wiebe for their helpful suggestions.

Correspondence concerning this article should be addressed to Gillian Mulvale, DeGroote School of Business, McMaster University, 1280 Main Street West, DSB 224, Hamilton, ON L8S 4M4; phone (905) 525-9140 ext. 24707; mobile (289) 983-0741; fax (905) 521-8995; email mulvale@mcmaster.ca. 


\section{RÉSUMÉ}

Afin de jeter les bases de ce numéro spécial intitulé Mettre en cuvre la Stratégie en matière de santé mentale pour le Canada: des perspectives canadiennes et d'ailleurs dans le monde, dans cet article, nous discutons d'abord du rôle des idées tel qu'il est rapporté dans la littérature sur les politiques publiques, ainsi que de l'influence de certaines grandes idées sur l'évolution des politiques en matière de santé mentale. Ensuite, en nous appuyant sur des recherches en politiques publiques et d'autres documents pertinents, de même que sur les points de vue de décideurs publics du domaine de la santé mentale (un échantillon de commodité que nous avons constitué), nous élaborons un modèle conceptuel qui intègre les notions de rétablissement et de bien-être. Ce modèle pourra servir d'outil aux décideurs qui ont à mettre en œuvre les idées transformatrices énoncées dans Changer les orientations - Stratégie en matière de santé mentale pour le Canada.

Mots clés : politiques en matière de santé mentale, idées, rétablissement, bien-être, modèle conceptuel intégré, transformation des systèmes de santé mentale

With the release of Changing Directions, Changing Lives: The Mental Health Strategy for Canada (Strategy), the Mental Health Commission of Canada (MHCC) has laid out a road map for mental health systems transformation in Canada (MHCC, 2012). It rests upon a paradigm shift in ideas about people with mental health problems and illnesses ${ }^{1}$ that states "At the core we are all the same. There is no us and them" (MHCC, 2009, p. 9). By adopting a comprehensive approach, the Strategy aims to ensure that people are no longer treated as two separate groups within the population, while recognizing the distinct needs of people at different times in their lives. This is critical for reducing the stigma that keeps people with mental health problems and illnesses from seeking care and being able to flourish in society (Corrigan \& Miller, 2004; Rüsch \& Corrigan, 2005; Stuart, Arboleda-Florez, \& Sartorius, 2012), and for promoting optimal mental health for the population as a whole. The paradigm shift in thinking captured in the Strategy started with the recommendations of the Senate report, Out of the Shadows at Last (Kirby \& Keon, 2006), and evolved through national consultations with thousands of individual Canadians and hundreds of stakeholder groups, and through careful review of the latest research and the experiences of other countries in developing national mental health strategies.

As members of the initial Strategy team at the MHCC, the authors were uniquely positioned at the vortex of the many ideas being suggested for the Strategy. As we heard support and critiques from stakeholders and reviewed the conceptual literature on recovery, mental health promotion, mental health and mental illness, our thinking crystalized into an integrated conceptual model that reflects the mental health needs of all Canadians and, potentially, brings seemingly disparate concepts and approaches into a coherent whole. We present the model in this special issue, in the hope that it will spark discussion about how integrated policy approaches may help to mobilize the transformative change called for in the Strategy, and bring an end to us-and-them thinking.

In the background section we discuss theories of how ideas can influence health policy-making, and briefly review how the evolution of core ideas about mental health and mental illness have contributed to paradigm shifts in mental health policy historically. We next examine the ideas that underlie the Strategy and how these were framed based on the public debate about its content during national consultations. Finally, 
we propose a conceptual model that can assist policy makers in bringing about transformative, "third order" change to mental health policy and service delivery in Canada (Hall, 1993).

\section{BACKGROUND}

\section{The Role of Ideas in Health Policy-Making}

The literature suggests that ideas matter in health policy-making. They shape how problems are understood and the solutions proposed. They work by inviting people to "think differently about their situation," providing information about alternatives, making some perspectives more or less salient, directing attention toward or away from particular phenomena, and leading to shifts in preferences or values (Weiss, 1990, p. 179). According to Beland (2009), ideas help to define policy problems, influence the content of reform proposals and act as "discursive weapons" in constructing the imperative for reform (p. 702). Competing portrayals of policy issues often influence whether or not policy problems and associated solutions gain the traction needed to make it onto the busy agendas of policy makers (Houston \& Richardson, 2000; Kingdon, 1995).

Although the traditional view is that ideas and information are relatively "soft" policy instruments (Doern \& Phidd, 1983), more recent literature has increasingly recognized ideas as a strong policy tool in their own right. Sets of ideas or policy paradigms can structure the policy-making process, "just as it can be structured by a set of institutions" (Hall, 1993, p. 290). Ideas and discourse are often critical for overcoming institutional constraints (Schmidt, 2010) and can be particularly important when confronting complex policy problems such as mental health (MacNaughton, Nelson, \& Goering, 2013; Mulvale, Chodos, Bartram, MacKinnon, \& Abud, 2014; Spillane, Reiser, \& Reimer, 2002). By first changing people's beliefs and preferences, ideas play a key role in changing people's behaviour (Hand, 2012).

Ideas-based policy instruments may be particularly well-suited to decentralized policy contexts, where command-and-control policy instruments are less available to federal policy makers (Howlett, 1991). Ideas may also be a powerful tool in governance contexts where non-governmental and quasi-governmental organizations and advisory committees share responsibilities in complex policy spaces (Howlett, 2000; Howlett, Kim, \& Weaver, 2005). The MHCC is an example of this kind of phenomenon. It was established as a quasigovernmental organization mandated by a federal government to build consensus for policy change within a decentralized context where provinces and territories have primary responsibility for setting government health policies, and managerial and clinical policy decisions are further devolved to health regions, organizations, networks, teams and individual clinicians. During its early years, the MHCC operated across an extensive structure of advisory committees and networks. In such contexts, ideas advanced at the national level can be translated into policy tools with more teeth at levels of governance that have the required jurisdiction or authority (Jordan, Rudiger, Zito, \& Bruckner, 2003).

Hall (1993) argues that ideas play a critical role in driving the kind of disruptive, third order change which is needed in mental health policy in Canada. First order change is characterized by keeping the same set of goals and policy instruments, but changing the settings of the instruments (for example, raising the tax rate). Second order change involves changes to the instruments but not the goals. By contrast, third order change is more disruptive. It shifts both the policy goals and the instruments used, and alters the constellation of actors and the discourse about the fundamental ideas within the prevailing policy regime. 
Hall (1993) further states that prevailing policy paradigms often become institutionalized in highly specialized and technical fields where experts play a key role, such as mental health care. In these fields most policy change is first or second order in nature and driven largely by government bureaucracies. When disruptive paradigm change is observed, it is typically driven by forces outside government, such as through extensive public debate and the media. Replacing fundamental ideas in a policy domain can lead to the establishment of new institutions and actors. Such change is more likely to be sustained if a coherent policy paradigm is in place that policy makers can point to in the presence of competing societal demands and resistance to change (Hall, 1993).

\section{The Role of Ideas in Mental Health Policy-Making}

A brief review of the history of mental health policy-making affirms the importance of ideas in driving third order, paradigm-shifting policy change (Hall, 1993). In the 1850s, ideas about "moral treatment" envisioned asylums as a place of respite from society (Wright, 2004). Dubbed "the institutionalization era," associated policies resulted in the development of institutions for treatment of people with mental illnesses over a period that lasted almost one hundred years (Kirby \& Keon, 2004; Rothman, 1990; Simmons, 1989). Exposés of human rights abuses gave rise to a reform movement centred around the idea of community-based treatment. When coupled with the discovery of new medications, this idea helped overcome policy legacies and led to a paradigm shift that transformed mental health policy and service delivery (Mulvale, Abelson, \& Goering, 2007). Weiss (1990) describes how during the deinstitutionalization era in the US between 1946 and 1963, the National Institute for Mental Health combined ideas about community-based care with small financial inducements such as scholarships to train mental health providers in new approaches to care. With legislated incentives for community-based treatment models, these professionals went on to develop and work in an array of new community-based organizations such as mental health centres and half-way houses.

During the 1970s, the idea of recovery-oriented mental health services began to gain momentum, driven by consumer/survivor/ex-patient social movements around the world (Freeze \& Walker Davis, 1997). In this context, recovery is based on the principle that people with mental health problems and illnesses should have greater control and responsibility for their lives, and represents a paradigm shift from a largely biological to a more holistic bio-psycho-social-spiritual understanding of mental illness and recovery. This shift coincided with the emergence of a professional psychiatric rehabilitation movement that recognized the value of community and work in the lives of people with mental illnesses (Jacobson \& Curtis, 2000). Despite some conceptual challenges such as the relationship between recovery and cure (Mulvale \& Bartram, 2009b), and critiques about the focus on individual responsibility rather than social and structural factors (Scott \& Lynere, 2011; Weisser, Morrow, \& Jamer, 2011), recovery has been the basis for a transformation in mental health policy-making and service delivery in several countries. These include the United Kingdom, Australia, New Zealand, and the United States (Commonwealth of Australia, 2009; Her Majesties' Government, 2010; Minister of Health, 2005; President's New Freedom Commission on Mental Health, 2003; Shepherd, Boardman, \& Slade, 2008; UK Department of Health, 2004).

More recently, mental health policy has embraced the idea of well-being, with a view to improving the quality of life, reducing the burden of disease, and increasing economic participation and productivity (European Union, 2008). Well-being draws from the fields of population health, mental health promotion, 
and mental illness prevention, where efforts to improve the overall mental health of the population are shifted "upstream" to include social determinants of health (Health and Welfare Canada, 1986; World Health Organization, 2005a). Well-being conceptualizes mental health as much more than the absence of mental illness (Canadian Institute for Health Information, 2011; World Health Organization, 2004). The well-being literature also emphasizes the potential return on investment through reduced "downstream" costs and improved productivity (Foresight Mental Capital and Wellbeing Project, 2008; Friedli \& Parsonage, 2009).

\section{Ideas That Informed the Mental Health Strategy for Canada}

Against this backdrop of changing policy ideas over time, the Strategy was developed between 2008 and 2012. In order to establish a framework of high-level goals for the Strategy, the MHCC undertook national consultations in 2009 on a draft framework for the Strategy, entitled Toward Recovery and WellBeing (Framework; MHCC, 2009). During the consultations, different constituencies in Canada appeared to place different emphasis on some of the more recent ideas discussed above. Some believed that recovery for people with mental health problems and illnesses should be the first goal of the Strategy, while others felt that a focus on mental health promotion/positive mental health for all people in Canada should take precedence. As participants in leading these consultations, what was particularly striking to the authors was the extent to which similar core principles were being expressed as different ideas and applied to different groups. Of particular note in this regard, one core set of principles pertained to mental health promotion and positive mental health for the whole population, while a similar set pertained to recovery of a meaningful life for people with mental health problems and illnesses (these principles are discussed in more detail below).

Emerging ideas in the policy dialogues and stakeholder discussions suggested a need for more integrative mental health policy. For example, feedback about the draft Framework's service delivery and prevention and promotion goals called for more collaboration and coordination across services, sectors and spheres (Ascentum, 2009). In addition, stakeholders indicated that ideas such as hope and recovery, holistic and person-centred service delivery, and the integration of social determinants needed to be woven into a comprehensive and integrative vision. Senior officials within provincial and territorial ministries of health suggested the need for a mental health strategy for all Canadians, one that was equally concerned with mental health promotion and recovery for people with mental health problems and illnesses.

During the consultations, an integrated vision began to emerge. People living with mental health problems and illnesses called for greater choice and self-determination, and for full inclusion in society. This input resulted in the evolution of the wording of the Framework's seventh goal from a focus on discrimination and stigma in the draft, to "People living with mental health problems and illnesses are fully included as valued members of society" in the final version (MHCC, 2009, p. 90). In parallel, a national Mental Health Promotion Think Tank recommended that "a comprehensive mental health policy must be built upon a mental health promotion framework," which would "increase opportunities for positive mental health for the entire population, including those with mental illness" (Pan-Canadian Planning Committee for Mental Health Promotion and Mental Illness Prevention, 2009, p. 1).

The Strategy was intended to be meaningful for all people in Canada, while ensuring the needs of people with mental illnesses remained a priority. These discussions therefore presented a conceptual challenge: how 
could the recovery orientation for people living with mental health problems and illnesses be reconciled with the whole population orientation of mental health promotion and positive mental health? Moreover, how could these approaches be integrated into a comprehensive understanding that could help to transform mental health policy-making across Canada? Drawing on consultations with stakeholders, the Framework responded to these challenges by setting out an integrated vision for the Strategy: "All people living in Canada have the opportunity to achieve the best possible mental health and well-being" (MHCC, 2009, p. 13).

In the next sections we propose a unified conceptual model for mental health policy that is consistent with the vision and recommendations of the Strategy. The conceptual model integrates core concepts from recovery and well-being. It provides a coherent policy paradigm, which Hall (1993) suggests can assist policy makers in their efforts to mobilize transformative change.

\section{METHODS}

The initial research to develop an integrated conceptual model was carried out during the process of developing the Framework (MHCC, 2009). The model was based on content analysis of various sources, including: (i) the academic literature which was searched using keywords related to the concepts of "recovery," "mental health promotion," "mental illness prevention," "well-being," and "positive mental health," and the mental health policy literature from Australia, New Zealand, the United Kingdom, the United States, the World Health Organization, the European Union, and provinces and territories from across Canada over the periods 1990 to 2009; (ii) data gathered during national consultations (Ascentum, 2009); (iii) discussions at meetings with provincial and territorial mental health officials and the MHCC's eight advisory committees; and (iv) feedback from national conferences in 2008 and 2009. Preliminary feedback on the proposed conceptual framework was sought during poster presentations at national conferences (Bartram, 2012; Mulvale \& Bartram, 2009a) and at a presentation at a Mental Health Leadership Assembly (Mulvale, 2012). In preparing this version of the model, the academic and policy literature was revisited to incorporate more recent developments.

While the authors' unique positioning allowed for rich and descriptive material (Seddoh \& Akortey Akor, 2012, p. 153), it could also be a source of professional bias (Walt, Shiffman, Schneider, Murray, Brugha, \& Gilson, 2008). In order to minimize such bias, a near final draft of the current paper was reviewed by a convenience sample $(n=9)$ of researchers and senior civil servants working in mental health policy at the federal, provincial or territorial level. This sample represented diverse perspectives from across the country, including mental health promotion, recovery, social inclusion, addictions, indigenous mental wellness, and broad social policy. A small focus group $(n=3)$, and a key informant interview with one policy maker (who was unable to attend the focus group) were also held by telephone. A semi-structured guide was used to gather participants' reactions to the proposed conceptual model in terms of clarity of concepts and potential usefulness as a basis for shifting ideas in mental health policy-making. The two authors independently analyzed the data gathered and were in agreement about the key themes that were raised during these discussions. The conceptual model was then revised to reflect the points of convergence in the discussions and suggestions made in the written feedback. Ethics approval was received from the McMaster and Carleton University Research Ethics Boards. 


\section{AN INTEGRATED CONCEPTUAL MODEL FOR RECOVERY AND WELL-BEING}

The proposed integrated model of recovery and well-being draws together many of the core concepts found in the literature, which have traditionally been treated separately. These include the two-continuum model of mental health and mental illness, shared recovery and mental health promotion principles and common elements in risk and protective factors and the social determinants of health.

\section{The Two-Continuum Model of Mental Health and Mental Illness}

The integrated model rests upon the two-continuum model of mental health and mental illness, which recognizes that mental health is more than the absence of mental illness (Health and Welfare Canada, 1988). The two-continuum model reflects the fact that a person may have poor mental health but no diagnosable mental illness. Similarly a person with a mental illness can experience a high level of mental health, in the sense of having a positive outlook, and feeling engaged and satisfied in life (see Figure 1). This approach

Figure 1

Two-Continuum Model of Mental Health and Mental Illness

\section{A Model of Mental Health \\ Optimal mental well-being (flourishing)}

e.g., a person who experiences a high level of mental well-being but who also has a diagnosis of a mental illness e.g., a person who has a high level of mental well-being and who has no mental illness

\section{Maximal mental} illness

e.g., a person experiencing mental illness who has a low level of mental well-being 
is in contrast to the traditional conception of mental health and mental illness as opposite poles on a single continuum. According to this set of ideas, people are considered to be mentally healthy if they do not have a mental disorder; otherwise, they are mentally ill. The single-continuum paradigm continues to shape many people's understandings of mental health and mental illness, as well as distinct approaches to policy and practice with respect to mental health promotion and treatment.

The continued dominance of the single-continuum paradigm is striking, given the evolving empirical evidence in support of the two-continuum model. For example, among an adult sample of Americans, Keyes (2002) found that $16.5 \%$ of those who have poor mental health ("languishing") had no symptoms of mental illness. Furthermore, $81.3 \%$ of the sample had less than optimal mental health ("flourishing"), which suggests that there is plenty of room to improve the mental health and well-being of the population. Finally, $23 \%$ of the sample that had symptoms of mental illness also had at least moderate mental health and another $6.5 \%$ had optimal mental health. These data suggest that recovery of a meaningful life among people with mental illness is more possible than traditionally thought. Canadian data also uphold this model, and suggest that a significantly greater proportion of the population is flourishing in Canada compared with the US (76.9\% vs. 18.7\%; Gilmour, 2014).

The integrated model takes the two-continuum model as its starting point and rotates it by $45^{\circ}$ to position optimal recovery and well-being at the top, in the direction of fewer symptoms of mental illness and the best possible mental health. It positions people at the centre of the model. The broken lines soften the distinctions between the quadrants of the two continuum model so that the central circle includes everyone, whether or not they are currently living with a mental illness, flourishing or languishing. The inner circular arrows indicate the dynamic movement of people between quadrants of the model at different times in their lives. For example, a person who is living with a mental illness may initially experience poor mental health but over the course of their recovery experience increasing mental health. Similarly a person who is flourishing may experience setbacks in life that lead to periods of languishing.

\section{Risk and Protective Factors and Social Determinants of Health}

In a similar manner, the literature on determinants of mental health, risk factors for mental illness and protective factors for mental health are traditionally considered separately, even though there is considerable overlap (Government of Canada, 2006; Public Health Agency of Canada, 2013). For example, coping skills are identified as a determinant of health, poor coping skills as a risk factor for mental illness, and resilience as a protective factor for mental health. Similarly, income and social status are determinants of health, low socio-economic status is a risk factor for mental illness, and high socio-economic status is a protective factor for mental health.

Each person's placement in the centre circle at a point in time reflects his or her particular mix of individual, social and structural risk and protective factors. These are shown at the centre of the sides of the integrated model (see Figure 2), because they can either support (an upward movement) or hamper (a downward movement) people's experiences of recovery and well-being. Individual factors include biology and genetics, personality traits, outlook on life, and level of resilience. Social factors include cultural practices and relationships among family members, friends, neighbours, and in the school or workplace. Structural factors relate to social determinants that affect health such as income, education, employment, housing, access 
Figure 2

Integrating Recovery and Well-Being into a Common Conceptual Model for Mental Health Policy

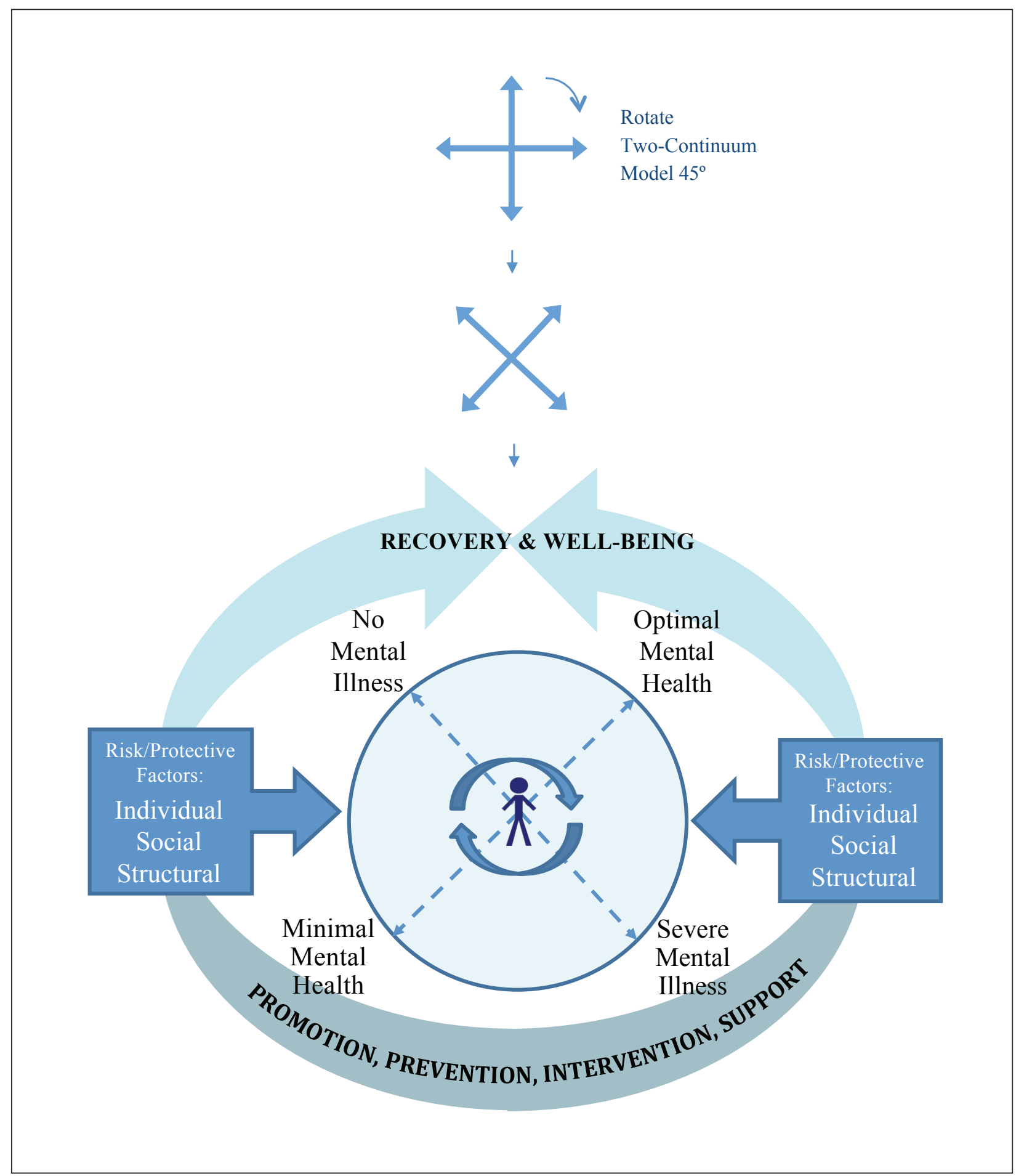


to health and social services, and freedom from discrimination (including discrimination against people living with mental health problems and illnesses, as well as racism, sexism, and homophobia). It is important to note that these factors are interdependent: research in the field of epigenetics demonstrates that complex interactions can occur between individual risk factors such as genetic predisposition and environmental factors that may be social or structural in nature. For example, experiences of trauma have been shown to modulate the genetic expression that influences risk of mental illnesses such as depression, schizophrenia and substance abuse (Tsankova, Renthal, Kumar, \& Nestler, 2007).

\section{Shared Recovery and Mental Health Promotion Principles}

Traditionally concepts of recovery and mental health promotion have similarly received separate treatment in the literature and in policy-making. The concept of recovery originated in the social movement described above for many people living with mental health problems and illnesses (Anthony, 1993; Davidson, Harding, \& Spanoil, 2005; Deegan, 1997; Jacobson \& Greenley, 2001). Recovery describes a deeply personal journey in which a person regains a satisfying, hopeful, and contributing life even in the presence of remaining limitations caused by illness (Anthony, 1993). Recovery does not take place in a vacuum; it builds on individual, family, social and cultural strengths, and is influenced by a broader set of social, political, and economic circumstances (MHCC, 2009).

In the field of mental health promotion, important ideas about well-being align closely with recovery principles as shown in Table 1. These include contributing to community, fulfilling one's potential, working productively and fruitfully, and having resilience (World Health Organization, 2005b). Mental health promotion, like recovery, adopts a strengths-based approach that speaks to the need for a meaningful life in the community, self-determination, hopefulness, the importance of the having one's basic needs met and rights upheld, and relationships with friends and family.

Recognizing these common elements, the conceptual model illustrates that there can be "upward" movement toward recovery and well-being that arises from improved mental health and well-being and/or reduced severity of mental health problems or illnesses, regardless of whether or not a person is currently experiencing symptoms. The trajectory will be unique for each person, with setbacks and periods of growth along the way. The model suggests that the differences between recovery and well-being may depend more on where people begin their journey and the nature of available supports or interventions, than on the desired endpoint of a meaningful life in the community, which is something widely shared. Moreover, the model highlights that recovery can be as much about improving one's mental health as it is about reducing symptoms of mental illness, and that movement toward well-being includes both improving mental health and preventing the onset of mental illness.

At the base of the model we situate resources for promotion, prevention, intervention, and support that can influence people's recovery and well-being. These resources serve as a foundation that people can draw on as they improve their recovery and well-being. We show these as an integrated part of improving people's recovery and well-being and as enveloping the whole population (represented by the inner circle) to denote that they must be accessible to everyone when required. To be effective, policy supports must meet people where they are and offer an integrated mix of promotion, prevention, and recovery-oriented intervention and support in a way that advances recovery and well-being depending on the starting point for 
Table 1

Definitions and Principles of Recovery and Well-being

\begin{tabular}{ll}
\hline Recovery & Mental health and well-being \\
\hline Definitions &
\end{tabular}

Living a satisfying, hopeful, and contributing life, even when there are on-going limitations caused by mental health problems and illnesses. (MHCC, 2012, p. 15)

A process in which people living with mental health problems and illnesses are empowered and supported to be actively engaged in their own journey of wellbeing. The recovery process builds on individual, family, cultural, and community strengths, and enables people to enjoy a meaningful life in their community while striving to achieve their full potential. (MHCC, 2009, p. 122)

\section{Principles}

- Hope, strengths-based, positive sense of future

- Empowerment

- Rights

- Dignity

- Respect

- Self-determination

- Choice

- Responsibility

- Taking control of life and health

- A home, a job, and a friend

- Social determinants of health

- Building a meaningful life

- Culturally-appropriate

- Holistic

- Person-centred

- A journey, non-linear

- Embedded in social context

- Builds on individual, family, cultural, and community strengths
Mental health is a state of well-being in which every individual realizes his or her own potential, can cope with the normal stresses of life, can work productively and fruitfully, and is able to make a contribution to her or his community. (World Health Organization, 2004, p. 10)

Mental health promotion aims to promote positive mental health by increasing psychological well-being, competence, and resilience, and by creating supportive living conditions and environments. (Saxena, JanéLlopis, \& Hosman, 2006, p. 6)
- Takes a positive perspective

- Individual and community empowerment and capacity-building

- Addresses inequities

- Enhances capacity to take control of life and health

- Promotes resiliency
- Relies on inter-sectoral linkages

- Collaboration

- Targets settings and population groups 
each person. These supports must also reflect a subtle but essential paradigm shift in thinking: that people share common objectives with respect to improving and maintaining mental health irrespective of whether they are living with a mental illness.

\section{DISCUSSION}

In light of the importance of ideas as a tool to achieve transformative, third-order change (Hall, 1993), the integrated conceptual model presented here may be a useful tool as an adjunct to the Strategy, and may point toward the next evolution of mental health policy thinking. The model's unique contribution is in integrating concepts from recovery, mental health promotion, and mental illness prevention, using the power of ideas to break down us-and-them thinking. The model presents a coherent singular focus on the well-being of all citizens. This singular focus may help to foster a paradigm shift where mental health becomes recognized as not just a priority for people living with mental health problems and illness and their families, but rather as everyone's issue. This expands the mental health policy debate beyond government departments of health and health promotion to include other segments of society such as social services, justice, the education system, and workplaces, as well as the media and the broader public.

Feedback gathered on this paper from policy makers confirmed the need for a unified approach to mental health policy that considers the mental health agenda in its entirety. In the absence of a unified approach, it is difficult for mental health issues to gain political traction when different constituencies lobby for treatment, promotion, early intervention, and for the needs of particular sub-populations. There was strong agreement that framing the mental health agenda for Canadians as one single issue would be beneficial from a policy perspective. Some policy makers suggested that "flourishing" or "vitality" for all could be the banner that policy makers could rally around, although a broader discussion of this point is required.

In terms of policy implications, while parallel independent activities to foster recovery and well-being respectively should continue, the model suggests that it is equally important to create opportunities to develop more integrative policy that simultaneously addresses both. Integrated policy approaches start from the assumption that fully realized mental health and well-being entails a common set of baseline needs: a home, a job, and a friend; healthy everyday environments in our communities and at home, school and work; and access to well-coordinated services, treatments, and supports when required. This means that opportunities to integrate policy exist at many levels (see Table 2). These include actions to address social determinants of health, efforts to raise awareness about mental health and mental illness, training and competency development for health and social service providers, and revisiting the design of service delivery.

Consistent with the Strategy, an integrated mental health policy approach would both re-orient existing resources across the full range of promotion, prevention, intervention and support envisioned in the integrated conceptual model, while also requiring increased spending across the board, consistent with the Strategy (MHCC, 2012, p. 126). Based on the US example referred to earlier (Weiss, 1990), targeted research grants and scholarships may aid in further developing and fostering uptake of integrated approaches. Joint training for new professionals, and competency development for the existing professional workforce on integrated approaches to recovery and well-being at the clinical and policy levels, may also help to advance their spread. There may also be simple, low cost activities that can be encouraged such as gratitude journals and random 
Table 2

Illustrative Examples of Opportunities to Integrate Policy Ideas

\begin{tabular}{ll}
\hline \multicolumn{1}{c}{ Policy Domain } & \multicolumn{1}{c}{ Opportunity } \\
\hline Social determinants of health & $\begin{array}{l}\text { Action to improve access to housing, education, income and employment can } \\
\text { simultaneously promote well-being, prevent mental illness and foster recovery. }\end{array}$ \\
\hline Raising awareness & $\begin{array}{l}\text { Equal emphasis on positive mental health and mental illness can be integrated } \\
\text { into public information campaigns, mental health literacy training and education } \\
\text { modules in schools, colleges, universities and workplaces. }\end{array}$ \\
\hline $\begin{array}{l}\text { Professional development and } \\
\text { training }\end{array}$ & $\begin{array}{l}\text { Provide competency development programs/continuing medical education } \\
\text { credits for existing health professionals. Develop professional training programs } \\
\text { for colleges and universities that emphasize the common foundation for } \\
\text { recovery and well-being. }\end{array}$ \\
\hline $\begin{array}{l}\text { Cross-departmental exchanges } \\
\text { and learning programs }\end{array}$ & $\begin{array}{l}\text { Establish joint workshops that include representatives of agencies and } \\
\text { departments of government to focus on health promotion, prevention, early } \\
\text { intervention and treatment that identifies potential areas of intersection and } \\
\text { develops associated programming. }\end{array}$ \\
\hline Re-orienting funding & $\begin{array}{l}\text { In addition to increasing overall funding, re-orient existing resources across the } \\
\text { full range of promotion, prevention, intervention and support envisioned in the } \\
\text { integrated conceptual model. }\end{array}$ \\
\hline $\begin{array}{l}\text { Health and social service } \\
\text { delivery }\end{array}$ & $\begin{array}{l}\text { Assessment, primary health care, and treatment can integrate evidence-based } \\
\text { interventions to improve well-being on a par with symptoms and extend this to } \\
\text { both mental and physical illness. }\end{array}$ \\
\hline $\begin{array}{l}\text { Adopting an integrated } \\
\text { approach across the lifespan }\end{array}$ & $\begin{array}{l}\text { Integrate approaches to prenatal care, early childhood, school-based programs, } \\
\text { workplace mental health, inclusive communities, integrated promotion and care } \\
\text { for seniors. }\end{array}$ \\
\hline
\end{tabular}

acts of kindness that evidence from the field of positive psychology suggests can make real, immediate, and sustainable improvements in well-being (Seligman, Steen, Nansook Park, \& Peterson, 2005) for all people regardless of where they are situated in the integrated conceptual model.

In terms of the lifespan, an integrated approach to mental health policy can begin with prenatal and early childhood programs, which can both promote maternal and child mental health, while also identifying mental health problems early and providing recovery-oriented care as needed. It would then progress to socio-emotional learning, fostering resilience and providing timely intervention and support to meet the mental health care needs of all children within the school setting. In workplaces, an integrated approach would open up conversations, and promote mental health literacy, workplace accommodations and comprehensive employee assistance programs. It would foster welcoming and inclusive mentally healthy communities designed to welcome all people whether they are flourishing or languishing, with or without a mental illness, and would continue to support the mental health and treatment needs of citizens as they age. 
It is essential that efforts to implement integrated policy approaches be rigorously evaluated. Indicators are currently being developed that can assist with this goal: in Scotland, on-going data is being collected to inform policy-making based on an integrated set of adult mental health indicators that include measures of both mental health and mental illness as well as the range of individual, community, and structural factors that support both recovery and well-being (Catto, 2012). This provides an opportunity to measure progress on integrated approaches to mental health policy-making. Canada has also moved in this direction with the addition of new measures of positive mental health to Statistics Canada's annual health survey (Statistics Canada, 2012).

The model also has implications for future research to support mental health policy development. We echo the increasing calls for integrated research on well-being, positive mental health, and recovery (Provencher \& Keyes, 2011; Slade, Adams, \& O’Hagan, 2012). For example, Provencher and Keyes (2011) have mapped six states of recovery against the two-continuum model, with "complete mental health recovery" representing both flourishing and the full remission of symptoms, in an effort to encourage research into recovery pathways. Future research could compare the impacts of usual care models for people experiencing a mental illness versus care that integrates mental health promotion activities and interventions from positive psychology. Other studies could investigate the impact of anti-stigma and mental health promotion initiatives that integrate information about recovery and well-being, in comparison with traditional approaches.

At the same time, it is important to recognize that this research has several limitations. While the model is rooted in areas of common ground across core ideas in mental health policy as posited in the academic literature, and responds to the need for a unified approach as identified by key informants, to date the model has only been validated with a convenience sample of researchers and policy makers. Although these participants represent diverse content areas and levels of government, the model would benefit from validation with a larger group of policy makers. Second, there are questions about the notable differences in estimates for the population proportions across the two continuum model in Canada and the US that warrants further investigation (Gilmour, 2014).

In light of these limitations, we present the model for discussion about its potential use as a coherent conceptual framework to help mobilize the ideas in the Strategy and to set the kind of unified policy goals that our informants indicate are needed to mobilize a much-needed unified policy agenda. As Hall (1993) indicates, public debate has a key role in driving third order change. We encourage debate and feedback about the proposed model and how it can be further refined and operationalized.

\section{CONCLUSION}

The health policy literature and brief review of the evolution of mental health policy-making suggest that ideas can be a key lever in transforming mental health policy and delivery. The integrated conceptual model can not only support policy makers and service providers in operationalizing the Mental Health Strategy for Canada, but also can inform broader efforts to transform mental health and related health and social service systems. The proposed model does this by eliminating the conceptual distinctions that have separated people living with mental health problems and illnesses from the rest of the population. It recognizes that the promotion of mental health is an integral part of recovery from mental illness and that action is needed 
on the individual, social, and structural factors that either promote or hinder both recovery and well-being. When these ideas are truly integrated, the model can help reduce the unnecessary compartmentalization of service delivery, and help to transform societal ideas about mental health and mental illness. Over time, the combined effects of normalization and integration can help reduce the stigmatization of people living with mental health problems and illnesses. We encourage readers to consider the model and how it can be refined and applied to the development of integrated approaches across Canada and elsewhere.

\section{NOTE}

1. In keeping with the approach taken in the Strategy, this paper intentionally adopts the term "mental health problem and illnesses" in order to be respectful of a wide range of views on controversies surrounding the choice of terminology (MHCC, 2012, p. 14).

\section{REFERENCES}

Anthony, W. (1993). Recovery from mental illness: The guiding vision of the mental health service system in the 1990s. Psychosocial Rehabilitation Journal, 16(11-23).

Ascentum. (2009). Setting the goals for a mental health strategy for Canada. Prepared for the Mental Health Commission of Canada. Retrieved May 28, 2015 from http://www.mentalhealthcommission.ca/English/system/files/private/ Diversity_Consultation_Report_Ch1-3_ENG_0.pdf

Bartram, M. (2012). Mental Health Strategy for Canada. Poster presented to the Chronic Disease Prevention Alliance of Canada Annual Conference, Ottawa, ON.

Beland, D. (2009). Ideas, institutions and policy change. Journal of European Public Policy, 16(5), 701-718.

Canadian Institute for Health Information. (2011). Recognizing and exploring positive mental health — policy dialogue: Synthesis and analysis. Ottawa, ON: Author.

Catto, S. (2012). Scotland's mental health: Adults 2012 briefing paper. Edinburgh: NHS Health Scotland.

Commonwealth of Australia. (2009). Fourth national mental health plan: An agenda for collaborative government action in mental health 2009-2014. Barton, ACT: Author.

Corrigan, P., \& Miller, F. (2004). Shame, blame, and contamination: A review of the impact of mental illness stigma on family members. Journal of Mental Health, 13(6), 537-548.

Davidson, L., Harding, C., \& Spanoil, L. (2005). Recovery from severe mental illnesses: Research evidence and implications for practice. Boston, MA: Boston University.

Deegan, P. (1997). Recovery and empowerment for people with psychiatric disabilities. Social Work in Health Care, 25(3), 11-24.

Doern, G. B., \& Phidd, R. W. (1983). Canadian public policy: Ideas, structure, process. Toronto, ON: Methuen.

European Union. (2008). European pact for mental health and well-being. Brussels: Author.

Foresight Mental Capital and Wellbeing Project. (2008). Final project report. London, UK: The Government Office for Science.

Freeze, F., \& Walker Davis, W. (1997). The consumer-survivor movement, recovery, and consumer professionals. Professional Psychology: Research and Practice, 28(3), 243-245.

Friedli, L., \& Parsonage, M. (2009). Promoting mental health and preventing mental illness: The economic case for investment in Wales. Cardiff: All Wales Mental Health Promotion Network.

Gilmour. (2014). Positive mental health and mental illness. Health Reports (Vol. 82-003-x). Ottawa, ON: Statistics Canada.

Government of Canada. (2006). The human face of mental health and mental illness in Canada. Ottawa, ON: Author.

Hall, P. (1993). Policy paradigms, social learning and the state: The case of economic policymaking in Britain. Comparative Politics, 25(3), 275-296.

Hand, L. (2012). Public policy design and assumptions about human behavior. Prepared for the 2012 Western Political Science Association Annual Conference. Retrieved from http://wpsa.research.pdx.edu/meet/2012/handlaura.pdf 
Health and Welfare Canada. (1986). Ottawa charter for health promotion. Ottawa, ON: Author.

Health and Welfare Canada. (1988). Mental health for Canadians: Striking a balance. Ottawa, ON: Health and Welfare Canada.

Her Majesties' Government. (2010). No health without mental health: A cross-government mental health strategy for people of all ages. London, UK: Her Majesties' Government.

Houston, D., \& Richardson, L. (2000). The politics of air bag safety: A competition among problem definitions. Policy Studies Journal, 28(3), 585-501.

Howlett, M. (1991). Policy instruments, policy styles, and policy implementation: National approaches to theories of instrument choice. Policy Studies Journal, 7(2), 1-21.

Howlett, M. (2000). Managing the "hollow state": Procedural policy instruments and modern governance as various functions and activities. Canadian Public Administration, 43(4), 412-431.

Howlett, M., Kim, J., \& Weaver, P. (2005). Assessing instrument mixes: Methodological issues in contemporary implementation research. Retrieved Aug. 12, 2014, from http://www.cpsa-acsp.ca/papers-2005/Howlett.pdf.)

Jacobson, N., \& Greenley, D. (2001). What is recovery? A conceptual model and explication. Psychiatric Services, $52(4), 482-485$.

Jacobson N., \& Curtis., L. (2000). Recovery as policy in mental health services: Strategies emerging from the States. Psychosocial Rehabilitation Journal, 23(4), 333-341.

Jordan, A., Rudiger, W., Zito, A., \& Bruckner, L. (2003). European governance and the transfer of 'new' environmental policy instruments (NEPIs) in the European Union. Public Administration Review, 81(3), 555-574.

Keyes, C. (2002). The mental health continuum: From languishing to flourishing in life. Journal of Health and Social Behavior, 43(2), 207-222.

Kingdon, J. W. (1995). Agendas, alternatives and public policies (2nd ed.). New York: Longman.

Kirby, M. J., \& Keon, W. J. (2004). Mental health policies and programs in selected countries: Report 2. Ottawa, ON: The Standing Senate Committee on Social Affairs, Science and Technology.

Kirby, M. J., \& Keon, W. J. (2006). Out of the shadows at last: Transforming mental health, mental illness and addiction services in Canada. Ottawa, ON: The Standing Senate Committee on Social Affairs, Science and Technology.

MacNaughton, E., Nelson, G., \& Goering, P. (2013). Bringing politics and evidence together: Policy entrepreneurship and the conception of the At Home/Chez Soi initiative for addressing homelessness and mental illness in Canada. Social Science \& Medicine, 82, 100-107.

Mental Health Commission of Canada. (2009). Toward recovery and well-being: A framework for a mental health strategy for Canada. Calgary, AB: Author.

Mental Health Commission of Canada. (2012). Changing directions, changing lives: The mental health strategy for Canada. Calgary, AB: Author.

Minister of Health. (2005). Te Tāhuhu: Improving mental health 2005-2015: The second New Zealand mental health and addiction plan. Wellington, NZ: Minister of Health.

Mulvale, G. (2012). The meaning of recovery for policy-making. Presentation to the Mental Health Leadership Assembly, Ottawa, ON.

Mulvale, G., Abelson, J., \& Goering, P. (2007). Mental health service delivery in Ontario, Canada: How do policy legacies shape prospects for reform? Health Economics, Policy and Law, 2(4), 363-389.

Mulvale, G., \& Bartram, M. (2009a). An integrated model of recovery and well-being. Poster Presentation at the MHCC Into the Light Conference, Vancouver, BC.

Mulvale, G., \& Bartram, M. (2009b). Recovery in the Canadian context: Feedback on the framework for mental health strategy development. Canadian Journal of Community Mental Health, 28(2), 7-15.

Mulvale, G., Chodos, H., Bartram, M., MacKinnon, M.-P., \& Abud, M. (2014). Engaging civil society through deliberative dialogue to create the first Mental Health Strategy for Canada: Changing Directions, Changing Lives. Social Science \& Medicine 123, 262-268.

Pan-Canadian Planning Committee for Mental Health Promotion and Mental Illness Prevention. (2009). Toward flourishing for all: National mental health promotion and mental illness prevention policy for Canadians. Retrieved Oct. 18, 2014, from http://sites.utoronto.ca/chp/mentalhealthpdffinal/Toward Flourishing for All Policy Recommendations Final April.pdf 
President's New Freedom Commission on Mental Health. (2003). Achieving the promise: Transforming mental health care in America. Retrieved May 27, 2015 from http:/govinfo.library.unt.edu/mentalhealthcommission/reports/ FinalReport/downloads/FinalReport.pdf

Provencher, H., \& Keyes, C. (2011). Complete mental health recovery: Bridging mental illness with positive mental health. Journal of Public Mental Health, 10(1), 57-69.

Public Health Agency of Canada. (2013). What makes Canadians healthy or unhealthy? Retrieved Oct. 19, 2014, from http://www.phac-aspc.gc.ca/ph-sp/determinants/determinants-eng.php

Rothman, D. (1990). The discovery of the asylum: Social order and disorder in the new republic. New York: Aldine de Gruyter.

Rüsch, N., \& Corrigan, P. (2005). Mental illness stigma: Concepts, consequences, and initiatives to reduce stigma. European Psychiatry, 20(8), 529-539.

Saxena, S., Jané-Llopis, J., \& Hosman, C. (2006). Prevention of mental and behavioural disorders: Implications for policy and practice. World Psychiatry, 5(1), 5-14.

Schmidt, V. (2010). Taking ideas and discourse seriously: Explaining change through discursive institutionalism as the fourth 'new institutionalism'. European Political Science Review, 2(1), 1-25.

Scott, A., \& Lynere, W. (2011). Valued identities and deficit identities: Wellness recovery action planning and selfmanagment in mental health. Nursing Inquiry, 18(1), 40-49.

Scottish Government. (2007). Towards a mentally flourishing Scotland: The future of mental health improvement in Scotland 2008-11. Edinburgh: Author.

Seddoh, A., \& Akortey Akor, S. (2012). Policy initiation and political levers in health policy: Lessons from Ghana's health insurance. BMC Public Health, 12(S1), S10.

Seligman, M., Steen, A., Nansook Park, N., \& Peterson, C. (2005). Positive psychology progress - empirical validation of interventions. American Psychologist, 60(5), 410-421.

Shepherd, G., Boardman, J., \& Slade, M. (2008). Making recovery a reality. London, UK: Sainsbury Centre for Mental Health.

Simmons, H. (1989). Unbalanced: Mental health policy in Ontario, 1930-1988. Toronto: Wall \& Thompson.

Slade, M., Adams, N., \& O’Hagan, M. (2012). Recovery: Past progress and future challenges. International Review of Psychiatry, 24(1), 1-4.

Spillane, J., Reiser, B., \& Reimer, T. (2002). Policy implementation and cognition: Reframing and refocusing implementation research. Review of Educational Research, 27(3), 387-431.

Statistics Canada. (2012). Canadian Community Health Survey: Annual Component. Retrieved Nov. 29, 2014, from http://www23.statcan.gc.ca/imdb/p2SV.pl?Function=getSurvey\&SDDS=3226

Stuart, H., Arboleda-Florez, J., \& Sartorius, N. (2012). Paradigms lost: Fighting stigma and the lessons learned. USA: Oxford University Press.

Tsankova, N., Renthal, W., Kumar, A., \& Nestler, E. (2007). Epigenetic regulation in psychiatric disorders. Nature Reviews Neuroscience, 8, 355-367.

UK Department of Health. (2004). The ten essential capabilities: A framework for the whole of the mental health workforce. London, UK: Author.

Walt, G., Shiffman, J., Schneider, H., Murray, S., Brugha, R., \& Gilson, L. (2008). 'Doing' health policy analysis: Methodological and conceptual reflections and challenges. Health Policy and Planning, 23, 308-317.

Weiss, J. (1990). Ideas and inducements in mental health policy. Journal of Policy Analysis and Management, 9(2), $178-190$.

Weisser, J., Morrow, M., \& Jamer, B. (2011). A critical exploration of social inequities in the mental health recovery literature. Vancouver, BC: Centre for the Study of Gender, Social Inequities and Mental Health.

World Health Organization. (2004). Promoting mental health. Geneva: Author.

World Health Organization. (2005a). Prevention of mental disorders: Effective interventions and policy options. Geneva: Author.

World Health Organization. (2005b). Promoting mental health: Concepts, emerging evidence, practice. Geneva: Author. Wright, D. (2004). The politics of mental health in Ontario: From asylum to integration. Presentation to the Shared Citizenship Public Lecture Series, University of Toronto, Toronto, ON. 


\title{
Pour qu'il n'y ait plus de « nous » et d' " eux » : un modèle conceptuel de politiques en matière de santé mentale qui intègre les concepts de rétablissement et de bien-être
}

\author{
Gillian Mulvale \\ Université McMaster \\ Mary Bartram \\ Université Carleton
}

\begin{abstract}
RÉSUMÉ
Afin de jeter les bases de ce numéro spécial intitulé Mettre en æuvvre la Stratégie en matière de santé mentale pour le Canada: des perspectives canadiennes et d'ailleurs dans le monde, dans cet article, nous discutons d'abord du rôle des idées tel qu'il est rapporté dans la littérature sur les politiques publiques, ainsi que de l'influence de certaines grandes idées sur l'évolution des politiques en matière de santé mentale. Ensuite, en nous appuyant sur des recherches en politiques publiques et d'autres documents pertinents, de même que sur les points de vue de décideurs publics du domaine de la santé mentale (un échantillon de commodité que nous avons constitué), nous élaborons un modèle conceptuel qui intègre les notions de rétablissement et de bien-être. Ce modèle pourra servir d'outil aux décideurs qui ont à mettre en œuvre les idées transformatrices énoncées dans Changer les orientations - Stratégie en matière de santé mentale pour le Canada.
\end{abstract}

Mots clés : politiques en matière de santé mentale, idées, rétablissement, bien-être, modèle conceptuel intégré, transformation des systèmes de santé mentale.

Gillian Mulvale, professeure adjointe, politiques et gestion de la santé, DeGroote School of Business, Université McMaster, Hamilton, Ontario ; Mary Bartram, School of Public Policy and Administration, Université Carleton, Ottawa, Ontario.

Les auteures remercient Howard Chodos, Marie Fast, Mary Pat MacKinnon, Katherine Scott, Colleen Simms, Robert Simpson, Heather Stuart et Patricia Wiebe pour leurs suggestions fort utiles.

Toute correspondance au sujet de cet article doit être adressée à Gillian Mulvale, DeGroote School of Business, McMaster University, 1280 Main Street West, DSB 224, Hamilton (Ontario) L8S 4M4 ; téléphone 905-525-9140, poste 24707 ; cellulaire 289-983-0741 ; télécopieur 905-521-8995 ; courriel mulvale@mcmaster.ca. 


\begin{abstract}
To set the stage for this special edition on Responses to the Mental Health Strategy for Canada: Canadian and International Perspectives on Mobilizing Change, we discuss the role of ideas in the public policy literature and the influence of key ideas over the history of mental health policy. Drawing on academic and policy literature and feedback from a convenience sample of mental health policy makers, we integrate the concepts of recovery and well-being into a conceptual model that can be used by policy makers as a tool to realize the transformative ideas captured in the Mental Health Strategy for Canada.
\end{abstract}

Keywords: mental health policy, ideas, recovery, well-being, integrated conceptual model, mental health systems transformation.

En publiant, en 2012, Changer les orientations, changer des vies - Stratégie en matière de santé mentale pour le Canada, la Commission de la santé mentale du Canada (CSMC) a tracé la voie menant à la transformation des systèmes de santé mentale au Canada (CSMC, 2012). Cette transformation s'appuie sur un changement du paradigme qui fonde les conceptions que nous avons des personnes vivant avec des troubles mentaux ou une maladie mentale ${ }^{1}$, changement qui mène à l'énoncé suivant : « À la base, nous sommes tous égaux : il n'y a pas de "nous" et d'“eux". » (CSMC, 2009, p. 9). En adoptant une approche qui englobe la totalité de la population, les concepteurs de la stratégie éliminent la séparation des citoyens en deux catégories, tout en reconnaissant que tous peuvent avoir des besoins particuliers à différents moments de leur vie. Faire nôtre cette idée de base est essentiel pour nous permettre d'atteindre deux objectifs : 1 . faire cesser la stigmatisation des personnes vivant avec des troubles mentaux ou une maladie mentale, parce que cette stigmatisation retient ces personnes de demander de l'aide et les empêche de s'épanouir dans leur communauté (Corrigan et Miller, 2004 ; Rüsch et Corrigan, 2005 ; Stuart, Arboleda-Florez et Sartorius, 2012) ; et 2. favoriser une santé mentale optimale dans l'ensemble de la population. Ce changement de paradigme présenté dans la stratégie tire son origine d'un rapport du Sénat intitulé De l'ombre à la lumière (Kirby et Keon, 2006) ; la formulation a ensuite évolué tout au long de consultations nationales auxquelles ont participé des milliers de Canadiens et des centaines de groupes d'intervenants, et à la suite d'un examen des plus récentes études dans le domaine et des façons dont d'autres pays ont entrepris d'élaborer une stratégie en matière de santé mentale.

En tant que membres de l'équipe initiale de la CSMC qui a élaboré la stratégie, nous avons eu un point de vue privilégié sur les multiples idées qui ont été suggérées tout au long du processus. En tenant compte de ce qu'ont suggéré divers intervenants et en passant en revue la littérature sur le rétablissement, la promotion de la santé mentale, la santé et la maladie mentales, nous avons petit à petit bâti un modèle conceptuel intégré qui pourrait refléter les besoins de l'ensemble des Canadiens en matière de santé mentale en réunissant en un tout cohérent des concepts et des approches en apparence disparates. En présentant ce modèle dans ce numéro spécial, nous souhaitons susciter des discussions sur la façon dont des politiques véritablement intégrées pourront contribuer à instaurer les changements que requiert la stratégie et à vaincre la conception selon laquelle nous partageons la population en « nous » et en « eux ».

Dans la première partie de l'article, «Le contexte », nous discutons d'abord des théories qui tentent d'éclairer la façon dont les idées influencent l'élaboration de politiques publiques, et nous rappelons l'évolution 
des idées de base sur la santé et la maladie mentales qui ont contribué, au cours des années, à modifier les paradigmes qui ont fondé les politiques en matière de santé mentale ; nous examinons ensuite les idées qui sous-tendent la stratégie proposée par la CSMC et nous expliquons comment celles-ci se sont structurées tout au long des consultations qui ont mené à cette stratégie. Puis, après une brève présentation de notre méthode, nous proposons un modèle conceptuel qui, nous l'espérons, aidera les décideurs politiques à mettre en œuvre les changements proposés - une « transformation de troisième ordre » de la politique canadienne en matière de santé mentale et de la prestation de services de santé mentale (Hall, 1993).

\section{LE CONTEXTE}

\section{Le rôle des idées dans l'élaboration des politiques publiques}

La recherche suggère que les idées sont importantes en matière d'élaboration de politiques publiques en matière de santé : elles influencent en effet la façon dont nous abordons et comprenons des problèmes et les solutions qui sont proposées. Elles nous invitent en fait à penser autrement des situations, en nous faisant considérer des solutions différentes et en nous faisant évaluer la plus ou moins grande importance de certains points de vue ; bref, les idées nous amènent à modifier nos préférences ou nos valeurs (Weiss, 1990, p. 179). Selon Béland (2009), les idées contribuent à la définition des problèmes qui sont à l'origine de politiques et elles influencent la teneur des réformes qui sont proposées, en plus d'agir en tant qu' « armes discursives » en établissant la nécessité des réformes à réaliser (p. 702, $n . t{ }^{1}$ ). En matière de questions stratégiques, des façons opposées de présenter certains problèmes et leurs solutions possibles peuvent en effet souvent contribuer à rendre ces questions suffisamment attractives pour que les décideurs politiques s'y intéressent véritablement (Houston et Richardson, 2000 ; Kingdon, 1995).

Même si l'on considère en général les idées et les informations comme des outils politiques relativement « faibles » (Doern et Phidd, 1983), la recherche récente reconnaît de plus en plus qu'il s'agit d'un véritable instrument politique «fort ». Des ensembles d'idées ou de paradigmes peuvent contribuer à structurer le processus d'élaboration de politiques « exactement comme le ferait un ensemble d'institutions » (Hall, 1993, p. 290, n. t.). Les idées et les discours jouent souvent un rôle essentiel pour permettre de surmonter des contraintes institutionnelles (Schmidt, 2010) ou dans le cas de questions stratégiques complexes comme la santé mentale (MacNaughton, Nelson et Goering, 2013 ; Mulvale et al., 2014 ; Spillane, Reiser et Reimer, 2002). Les idées, en amenant les gens à modifier leurs croyances et leurs préférences, agissent ensuite sur les comportements (Hand, 2012).

Les instruments de politiques qui s'appuient sur des idées sont bien adaptés aux contextes où le pouvoir est décentralisé, puisque les décideurs politiques ne disposent pas alors d'autant d'outils contraignants que là où le pouvoir est centralisé - c'est par exemple le cas du gouvernement fédéral canadien en matière de santé (Howlett, 1991). Les idées peuvent aussi être un instrument puissant dans un contexte où des organisations non gouvernementales ou quasi gouvernementales et des comités consultatifs jouent un rôle important dans

${ }^{1}$ Certaines des citations que comporte la version originale anglaise de cet article sont tirées d'ouvrages ayant déjà été traduits en français : quand c'est le cas, les citations présentées dans la version française sont tirées des traductions françaises de ces ouvrages. Sinon, les citations sont accompagnées de $n$. $t$. (notre traduction). 
des espaces politiques complexes (Howlett, 2000 ; Howlett, Kim et Weaver, 2005) : la situation qui nous intéresse ici en est un bon exemple. En effet, c'est à la CSMC, une organisation quasi gouvernementale, que le gouvernement fédéral a confié le mandat de tenter d'établir un consensus en ce qui a trait à la transformation de la politique canadienne en matière de santé mentale ; or, au Canada, la santé est une compétence provinciale et territoriale et, de plus, une fois que les provinces et les territoires ont adopté leur stratégie en cette matière, ce sont des régions, des organismes, des réseaux et des cliniciens qui établissent les lignes de conduite et prennent les décisions cliniques. Durant ses premières années d'existence, la CSMC a travaillé en s'appuyant sur plusieurs comités consultatifs et de nombreux réseaux; dans un tel contexte, il est possible de traduire les idées avancées au niveau national en instruments de politiques qui seront vraiment efficaces aux paliers de gouvernement qui ont les compétences pour agir (Jordan et al., 2003).

Par ailleurs, Hall (1993) affirme que les idées jouent un rôle majeur sur le plan des politiques en matière de santé mentale au Canada, puisque que le changement à faire en est un de troisième ordre. Dans le cas d'un changement de premier ordre, l'ensemble d'objectifs et d'outils politiques reste le même, et ce ne sont que les paramètres d'utilisation des outils qui changent (une augmentation d'impôt, par exemple). Un changement de deuxième ordre implique pour sa part l'utilisation de nouveaux outils, en vue d'atteindre des objectifs qui restent les mêmes. Enfin, un changement de troisième ordre est plus profond : il s'agit d'une modification qui touche à la fois les objectifs d'une politique et les outils utilisés pour mettre celle-ci en œuvre ; cette modification implique donc une réorganisation de la constellation des acteurs concernés et la transformation du discours qui prévalait au départ sur les idées qui constituaient les fondements de la politique.

Hall (1993) explique également que, avec le temps, les paradigmes sur lesquels s'appuient des politiques s'institutionnalisent et acquièrent un caractère hautement spécialisé et technique, ce qui donne par conséquent un très grand pouvoir aux spécialistes et aux experts - le domaine des soins de santé mentale en est un bon exemple. Dans ce type de domaine, la plupart des changements de politiques sont par nature de premier ou de deuxième ordre, et amorcés par la bureaucratie. Quand des changements plus profonds se produisent, c'est que le mouvement est porté par des forces extérieures aux gouvernements, par exemple grâce à un large débatpar exemple d'un large débat mené dans la population. Modifier les idées fondamentales sur lesquelles s'appuient des politiques peut donc mener à l'émergence de nouvelles institutions et de nouveaux acteurs ; et de tels changements sont plus susceptibles d'être réalisés si, pour convaincre les citoyens de la nécessité d'un changement, les décideurs ont un paradigme cohérent et convaincant à proposer qui sera préféré aux points de vue adverses et qui permettra ainsi de vaincre la résistance au changement (Hall, 1993).

\section{Le rôle des idées dans l'élaboration de politiques en matière de santé mentale}

Un survol de l'évolution des politiques publiques en matière de santé mentale montre l'importance du rôle que jouent les idées en tant que moteurs de changements de troisième ordre, c'est-à-dire de changements qui concernent les paradigmes qui fondent les politiques (Hall, 1993). Ainsi, durant les années 1850, la notion de « traitement moral » était à la base du rôle que l'on donnait aux asiles, c'est-à-dire celui d'offrir aux malades un répit en marge de la société (Wright, 2004). L'« ère de l'institutionnalisation » a alors donné lieu, pendant presque un siècle, à la mise sur pied d'institutions où l'on traitait les personnes vivant avec des troubles mentaux ou une maladie mentale (Kirby et Keon, 2004 ; Rothman, 1990 ; Simmons, 1989).

La multiplication de révélations portant sur des violations des droits de la personne dans les asiles a ensuite 
engendré un mouvement de réforme fondé sur l'idée de soins dans la communauté ; associée à la découverte de certains médicaments, cette idée a contribué au renversement de l'influence des politiques en place et à un changement du paradigme sur lequel celles-ci s'appuyaient - ce qui a permis de modifier les politiques en matière de santé mentale et, par conséquent, le type de services offerts et la façon de les offrir (Mulvale, Abelson et Goering, 2007). Weiss (1990) explique, par exemple, comment, pendant la période de la désinstitutionnalisation aux États-Unis entre 1946 et 1963, le National Institute for Mental Health a conjugué le concept de soins dans la communauté et l'offre d'incitatifs financiers - des bourses d'étude, par exemple - pour encourager la formation des soignants pour qu'ils se familiarisent avec de nouvelles méthodes; grâce à des incitatifs liés à l'approche de soins dans la communauté, par exemple, des professionnels ont ainsi mis en place divers organismes communautaires, comme des centres de santé mentale et des maisons de transition.

Au cours des années 1970, le concept de services de santé mentale axés sur le rétablissement s'est graduellement répandu, grâce à des mouvements de consommateurs-bénéficiaires/survivants/ex-patients qui l'ont défendu partout dans le monde (Freeze et Walker Davis, 1997). Dans ce contexte, le sens donné au terme « rétablissement » est lié au principe selon lequel les personnes vivant avec des troubles mentaux ou une maladie mentale doivent avoir plus de pouvoir sur leur vie; cela constitue un changement de paradigme, puisque la compréhension que l'on avait jusque-là de la maladie mentale est modifiée : alors qu'elle était au départ surtout biologique, elle devient holistique (bio-psycho-socio-spirituelle), comme doit aussi l'être le rétablissement. Ce changement a coïncidé avec l'émergence d'un mouvement de réhabilitation psychiatrique qui reconnaissait l'importance de la communauté et la valeur du travail pour les personnes ayant une maladie mentale (Jacobson et Curtis, 2000). La notion de rétablissement - malgré quelques difficultés conceptuelles, touchant entre autres la relation entre rétablissement et guérison (Mulvale et Bartram, 2009b) et en dépit des critiques selon lesquelles cela donnait plus d'importance à la responsabilité individuelle plutôt qu'à des facteurs sociaux et structurels (Scott et Lynere, 2011 ; Weisser, Morrow et Jamer, 2011) - a constitué la base de la transformation des politiques en matière de santé mentale et de la prestation de services dans plusieurs pays, dont le Royaume-Uni, l'Australie, la Nouvelle-Zélande et les États-Unis (Commonwealth of Australia, 2009 ; Her Majesties' Government, 2010 ; Minister of Health, 2005 ; President's New Freedom Commission on Mental Health, 2003 ; Shepherd, Boardman et Slade, 2008 ; UK Department of Health, 2004).

Plus récemment, au concept de de rétablissement s'est ajouté celui de bien-être, ce qui a permis d'inclure les notions d'amélioration de la qualité de vie, de réduction du fardeau de la maladie et de participation accrue à la vie économique et à la productivité (European Union, 2008). Ce concept tire son origine des domaines de la santé de la population, de la promotion de la santé mentale et de la prévention de la santé mentale : l'objectif étant, " en amont », de favoriser une meilleure santé mentale pour l'ensemble des citoyens, les déterminants sociaux de la santé deviennent donc des facteurs dont il faut tenir compte (Health and Welfare Canada, 1986 ; World Health Organization, 2005a), et la santé mentale est ainsi vue comme étant plus que la simple absence d'une maladie mentale (Canadian Institute for Health Information, 2011 ; World Health Organization, 2004). Dans la littérature sur le sujet, on évoque également le rendement potentiel de certains investissements visant à améliorer le bien-être, cela ayant pour effet de réduire certains coûts « en aval » et d'améliorer la productivité (Foresight Mental Capital and Wellbeing Project, 2008 ; Friedli et Parsonage, 2009). 


\section{Les idées qui ont guidé l'élaboration de la stratégie canadienne en matière de santé mentale}

C'est sur cette évolution des idées que s'est appuyée, de 2008 à 2012, l'élaboration de la stratégie canadienne en matière de santé mentale. Dans une première étape, afin d'établir les objectifs de la stratégie, la CSMC a décidé d'établir le cadre de la stratégie, à partir duquel elle mènerait des consultations. Les premières consultations ont porté sur une ébauche de ce cadre, dont la version finale a été par la suite publiée en 2009 dans un rapport intérimaire intitulé Vers le rétablissement et le bien-être-Cadre pour une stratégie en matière de santé mentale au Canada (CSMC, 2009). Les consultations ont permis de constater que les participants ne s'entendaient pas sur le concept qu'il fallait prioriser parmi ceux que nous avons décrits plus haut ; certains avançaient que le rétablissement chez les personnes vivant avec des troubles mentaux ou une maladie mentale devait être le premier objectif de la stratégie, alors que d'autres étaient d'avis qu'il fallait d'abord mettre l'accent sur la promotion de la santé mentale et une meilleure santé mentale pour l'ensemble des citoyens. Pour nous, qui avons participé à la réalisation de ces consultations, ce qui a été le plus étonnant a été de réaliser que des participants comprenaient certains concepts de base de manières différentes, et qu'ils liaient leur application à des groupes différents. Par exemple, certains associaient un ensemble de concepts à la promotion de la santé mentale et à une meilleure santé mentale pour l'ensemble des citoyens, alors que d'autres associaient un autre ensemble de concepts similaires au retour à une vie épanouissante pour les personnes vivant avec un trouble mental ou une maladie mentale (ces principes sont présentés en détail plus loin).

Une idée est toutefois ressortie des consultations et des discussions avec des intervenants concernés : celle de la nécessité d'une politique qui intégrerait mieux les différents concepts en question. Par exemple, face aux objectifs (présentés dans l'ébauche de cadre) liés à la prestation de services et à la prévention et à la promotion de la santé mentale, certains ont réclamé une meilleure coordination entre les services et les différents secteurs (Ascentum, 2009). Des intervenants ont également avancé que certains concepts (comme l'espoir et le rétablissement), la notion de services holistiques et axés sur la personne ainsi que la prise en compte des déterminants sociaux devaient être intégrés dans une seule et même vision globale. Des hauts fonctionnaires des ministères de la Santé provinciaux et territoriaux ont expliqué qu'il fallait élaborer une stratégie nationale en matière de santé mentale qui concernerait tous les Canadiens, et qui viserait à la fois la promotion de la santé mentale et le rétablissement pour les personnes vivant avec des troubles mentaux ou une maladie mentale.

Une vision intégrée de la politique à élaborer a ainsi commencé à émerger. Des gens vivant avec des troubles mentaux ou une maladie mentale ont par ailleurs réclamé qu'on leur offre un plus grand choix de services, de soins et de formes de soutien, qu'on leur donne plus de pouvoir, et qu'ils soient pleinement intégrés dans la société. Par conséquent, la formulation du septième grand objectif présenté dans l'ébauche de cadre a évolué afin que l'on accorde plus d'importance à la lutte contre la discrimination et la stigmatisation; dans dans le rapport intérimaire, l'objectif a donc été défini comme suit : « Les personnes vivant avec des troubles mentaux ou une maladie mentale sont entièrement intégrées à titre de membres de la société. » (CSMC, 2009, p. 90) En parallèle, un groupe de réflexion national sur la promotion de la santé mentale a recommandé qu' « une politique globale en matière de santé mentale soit élaborée à partir d'un cadre lié à promotion de la santé mentale », afin de «favoriser une meilleure santé mentale dans l'ensemble de la 
population, ce qui inclut les personnes vivant avec une maladie mentale » (Pan-Canadian Planning Committee for Mental Health Promotion and Mental Illness Prevention, 2009, p. 1, n. t.).

Autrement dit, on s'entendait sur le fait que la stratégie devait s'appliquer à tous les Canadiens, tout en permettant d'assurer que les besoins les personnes vivant avec une maladie mentale restent une priorité. Cela posait un défi : comment concilier les deux grandes orientations - le rétablissement, pour les personnes vivant avec des troubles mentaux ou une maladie mentale d'une part, et la promotion de la santé mentale et une meilleure santé mentale pour l'ensemble des citoyens d'autre part? De plus, comment intégrer ces deux approches dans une compréhension globale de la santé mentale qui permette de transformer l'élaboration des politiques en matière de santé mentale partout au Canada? Grâce aux nombreux points de vue recueillis pendant les consultations, la réponse à cette question a été donnée grâce à la formulation suivante : « Toutes les personnes qui habitent le Canada ont la possibilité d'atteindre le meilleur état de santé mental et de bienêtre possible », lit-on dans le rapport intérimaire (CSMC, 2009, p. 13)

Dans la suite de l'article, nous proposons donc un modèle conceptuel intégré qui peut servir de point de départ à des politiques en matière de santé mentale. Ce modèle est en accord avec l'orientation et les recommandations de la stratégie ; il intègre les concepts de rétablissement et de bien-être ; et il offre un paradigme cohérent pouvant soutenir ces politiques, et donc, selon Hall (1993), appuyer les décideurs dans leur travail de mobilisation de toutes les forces nécessaires pour transformer les systèmes de santé mentale.

\section{LA MÉTHODE}

C'est pendant le processus d'élaboration du cadre de la stratégie (CSMC, 2009) que nous avons fait les premières recherches afin de concevoir un modèle conceptuel intégré. Nous avons alors consulté diverses sources : i) des études universitaires recensées grâce à des mots clés liés aux concepts suivants : « recovery » ( « rétablissement »), « mental health promotion » (« promotion de la santé mentale »), « mental illness prevention » (« prévention de la maladie mentale »), « well-being » ( « bien-être ») et « positive mental health » (« santé mentale positive », «santé mentale »), ainsi que la littérature portant sur les politiques en matière de santé mentale de l'Australie, de la Nouvelle-Zélande, du Royaume-Uni, des États-Unis, de l'Organisation mondiale de la santé, de l'Union européenne et des provinces et des territoires canadiens durant la période 1990-2009; ii) les données recueillies durant les consultations (Ascentum, 2009) ; iii) les discussions avec des fonctionnaires des provinces et des territoires et avec les membres des huit comités consultatifs de la CSMC; et iv) les commentaires des participants recueillis pendant les conférences nationales de 2008 et 2009. Nous avons établi une première version de notre modèle, et nous l'avons présenté au moyen d'une affiche aux conférences nationales (Bartram, 2012 ; Mulvale et Bartram, 2009a) et grâce à un exposé à la Conférence nationale sur le leadership en santé (Mulvale, 2012). Nous avons alors revu le modèle à la lumière des réactions qu'il avait ainsi suscitées, nous avons également fait une nouvelle revue de littérature pour y intégrer les développements les plus récents, et nous en sommes arrivées à la version que nous présentons ici.

Notre rôle de participantes à l'élaboration de la stratégie canadienne nous a permis d'avoir accès à de précieuses informations (Seddoh et Akortey Akor, 2012, p. 153); par contre cela pouvait aussi être une source de biais (Walt et al., 2008). C'est pourquoi nous avons demandé à des chercheurs et à des hauts 
fonctionnaires liés aux politiques de santé mentale aux niveaux fédéral, provincial et territorial (un échantillon de commodité, $n=9$ ) de lire une version presque finale de cet article ; cet échantillon était représentatif de divers points de vue sur les sujets concernés recueillis dans l'ensemble du pays (promotion de la santé mentale, rétablissement, inclusion sociale, dépendances, bien-être mental des Autochtones) ainsi que du domaine des politiques publiques de façon plus large. Nous avons aussi interrogé pendant des conversations téléphoniques un petit groupe de réflexion $(n=3)$ et une personne impliquée dans l'élaboration de politiques (qui ne pouvait pas participer au groupe); nous avons recueilli leurs commentaires sur notre modèle (en utilisant un guide semi-structuré) en visant deux principaux objectifs, nous assurer que les concepts utilisés étaient clairs et que le modèle pouvait servir de base aux changements à réaliser dans l'élaboration de politiques en matière de santé mentale. Nous avons revu les données que nous avions recueillies de façon indépendante (chacune de notre côté, sans nous consulter) et nous avons constaté que nous en faisions la même analyse. Nous avons ensuite révisé notre modèle pour qu'il reflète les points de convergence et les suggestions que nous avions recueillies par écrit ; puis les comités d'éthique en recherche des universités McMaster et de Carleton l'ont approuvé.

\section{UN MODÈLE CONCEPTUEL QUI INTÈGRE LES CONCEPTS DE RÉTABLISSEMENT ET DE BIEN-ÊTRE}

Notre modèle réunit des concepts importants présents dans la littérature, mais qui, traditionnellement, étaient abordés séparément : 1 . le modèle à deux continuums de santé mentale et de maladie mentale ; 2 les facteurs de risque et de protection et les déterminants sociaux de la santé ; et 3. les principes communs aux concepts de rétablissement et de promotion de la santé mentale.

\section{Le modèle à deux continuums de santé mentale et de maladie mentale}

Notre modèle se base sur le modèle à deux continuums de santé mentale et de maladie mentale, qui est lui-même fondé sur la définition de la santé mentale comme étant plus que la seule absence de maladie mentale (Health and Welfare Canada, 1988). Selon le modèle à deux continuums, une personne peut être en mauvaise santé mentale sans qu'on lui ait pourtant diagnostiquer de maladie mentale ; de la même façon, une personne vivant avec une maladie mentale peut éprouver un haut niveau de santé mentale, c'est-à-dire avoir une attitude positive et mener une vie qui est, pour elle, intéressante et satisfaisante (voir la figure 1). Par contraste, selon la conception traditionnelle de la santé mentale et de la maladie mentale, on considère ces deux phénomènes comme des pôles opposés sur un seul continuum : une personne est dite en bonne santé mentale si elle ne souffre pas de trouble mental; dans le cas contraire, cette personne est dite « malade mentale ». Ce paradigme influence encore aujourd'hui la compréhension qu'ont de nombreuses personnes de la santé mentale et de la maladie mentale, ce qui mène donc à des stratégies et à des pratiques isolées les unes des autres, puisque liées d'un côté à la promotion de la santé mentale et de l'autre au traitement de la maladie mentale.

La persistance du modèle à continuum unique a quelque chose d'étonnant, puisque la recherche empirique soutient la valeur du modèle à deux continuums. Par exemple, Keyes (2002) a observé, dans un échantillon d'adultes américains, que 16,5\% de ceux qui avaient une mauvaise santé mentale (dite « languissante », de 
l'anglais languishing, c'est-à-dire caractérisée par de l'indolence, de la léthargie, de l'apathie et de faibles niveaux de bien-être émotionnel et de fonctionnement positif) n'avaient aucun symptôme de maladie mentale ; de plus, la santé mentale de $81,3 \%$ des participants était inférieure à une santé mentale optimale (dite « florissante », de l'anglais flourishing, c'est-à-dire caractérisée par des niveaux élevés de bien-être émotionnel et de fonctionnement positif), ce qui démontre qu'il y a place pour de l'amélioration chez de très nombreuses personnes en matière de santé mentale et de bien-être ; enfin, parmi les participants qui éprouvaient des symptômes de maladie mentale, $23 \%$ avaient pourtant une santé mentale moyenne et $6,5 \%$ une très bonne santé mentale. Ces données suggèrent que les gens qui vivent avec une maladie mentale peuvent, beaucoup plus qu'on ne le croyait généralement autrefois, vivre une vie épanouissante. Des recherches canadiennes soutiennent aussi le modèle à deux continuums; elles indiquent entre autres que, au Canada, une proportion beaucoup plus importante de la population est en très bonne santé mentale en comparaison avec ce que l'on observe aux États-Unis (76,9\% contre 18,7\%) (Gilmour, 2014).

Figure 1

Modèle à deux continuums de santé et de maladie mentales

\begin{tabular}{|c|c|}
\hline \multicolumn{2}{|c|}{ Un modèle de santé mentale } \\
\hline \multicolumn{2}{|c|}{$\begin{array}{l}\text { Bien-être mental optimal } \\
\text { (flourishing : niveaux élevés de bien-être émotionnel et de fonctionnement) }\end{array}$} \\
\hline $\begin{array}{l}\text { p. ex. une personne qui a un niveau } \\
\text { élevé de bien-être mental mais chez } \\
\text { laquelle on a aussi diagnostiqué une } \\
\text { maladie mentale }\end{array}$ & $\begin{array}{l}\text { p. ex. une personne qui a un niveau } \\
\text { élevé de bien-être mental mais qui } \\
\text { n'a pas de maladie mentale }\end{array}$ \\
\hline $\begin{array}{l}\text { Santé mentale } \\
\text { maximale }\end{array}$ & $\begin{array}{l}\text { Santé mentale } \\
\text { minimale }\end{array}$ \\
\hline $\begin{array}{l}\text { p. ex. une personne qui vit avec une } \\
\text { maladie mentale et a aussi un faible } \\
\text { niveau de bien-être mental }\end{array}$ & $\begin{array}{l}\text { p. ex. une personne chez laquelle on } \\
\text { n'a pas diagnostiqué de maladie } \\
\text { mentale mais qui a un faible niveau } \\
\text { de bien-être mental }\end{array}$ \\
\hline \multicolumn{2}{|c|}{$\begin{array}{l}\text { Bien-être mental minimal } \\
\text { (languishing : faibles niveaux de bien-être émotionnel et de fonctionnement) }\end{array}$} \\
\hline
\end{tabular}

Source : Scottish Government, 2007. 
Concrètement, pour obtenir notre modèle intégré, on fait pivoter à $45^{\circ}$ le modèle à deux continuums, pour que le rétablissement et le bien-être optimaux se retrouvent au sommet, dans l'axe du plus petit nombre de symptômes de maladie mentale et donc de la meilleure santé mentale possible. Les personnes sont alors placées au centre du modèle. Les lignes pointillées permettent d'atténuer les distinctions que font les quadrants du modèle à deux continuums : le cercle central inclut ainsi l'ensemble des citoyens, qu'ils vivent ou non avec une maladie mentale, et que leur état soit caractérisé par des niveaux élevés de bien-être émotionnel et de fonctionnement positif («florissant») ou par de l'indolence, de la léthargie, de l'apathie et de faibles niveaux de bien-être émotionnel et de fonctionnement positif (« languissant»). Les flèches du cercle intérieur indiquent le mouvement dynamique des personnes entre les quadrants du modèle et à différent moments de leur vie. Par exemple, une personne vivant avec une maladie mentale peut au départ avoir une mauvaise santé mentale, mais, pendant son parcours de rétablissement arriver à vivre une meilleure santé mentale; de la même façon, une personne dont l'état est « florissant » peut à certains moments faire face à des difficultés et vivre des périodes d'état « languissant».

\section{Les facteurs de risque et de protection et les déterminants sociaux de la santé}

Très souvent, dans la littérature, on a traditionnellement considéré les déterminants de la santé mentale, d'une part, et les facteurs de risque de maladie mentale et de protection de la santé mentale, d'autre part, comme des éléments isolés les uns des autres, alors que, en réalité, ils se chevauchent de plusieurs façons (Government of Canada, 2006 ; Public Health Agency of Canada, 2013). Par exemple, les capacités d'adaptation sont l'un des déterminants de la santé mentale : de faibles capacités d'adaptation sont donc un facteur de risque, et la résilience un facteur de protection. De la même façon, le revenu et le statut social sont des déterminants de la santé mentale : un faible statut socioéconomique est donc un facteur de risque, et un statut socioéconomique élevé un facteur de protection.

La position de chaque personne dans le cercle central à un point dans le temps correspond à une combinaison particulière de facteurs individuels, sociaux et structurels de risque et de protection. Ces différents facteurs apparaissent au milieu, de chaque côté du modèle (voir la figure 2), ce qui illustre qu'ils peuvent soit soutenir (mouvement ascendant) soit freiner (mouvement descendant) le rétablissement et le bien-être. Rappelons brièvement quels sont ces facteurs de risque et de protection. Les facteurs individuels sont la biologie et la génétique, les traits de personnalité, l'attitude dans la vie et le degré de résilience. Les facteurs sociaux sont les pratiques culturelles et les liens avec les membres de la famille, les amis et les voisins, et avec les pairs à l'école et au travail. Les facteurs structurels sont liés aux déterminants sociaux qui influencent la santé, comme le revenu, le degré de scolarité, l'emploi, le logement, l'accès à des services de santé et sociaux et la la présence plus ou moins marquée de discrimination (la discrimination envers les gens vivant avec un trouble mental ou une maladie mentale, le racisme, le sexisme et l'homophobie). Ces différents facteurs sont interdépendants, comme l'a montré la recherche. Par exemple, des études dans le domaine de l'épigénétique ont permis d'établir la présence d'interactions complexes entre des facteurs de risque individuels (comme des prédispositions génétiques) et des facteurs environnementaux (de nature sociale ou structurelle) : on sait en effet que des traumatismes peuvent moduler l'expression de gènes qui influencent le risque de certaines maladies mentales, comme la dépression, la schizophrénie et la toxicomanie (Tsankova et al., 2007). 


\section{Figure 2}

Intégration des concepts de rétablissement et de bien-être dans un modèle conceptuel de politiques en matière de santé mentale

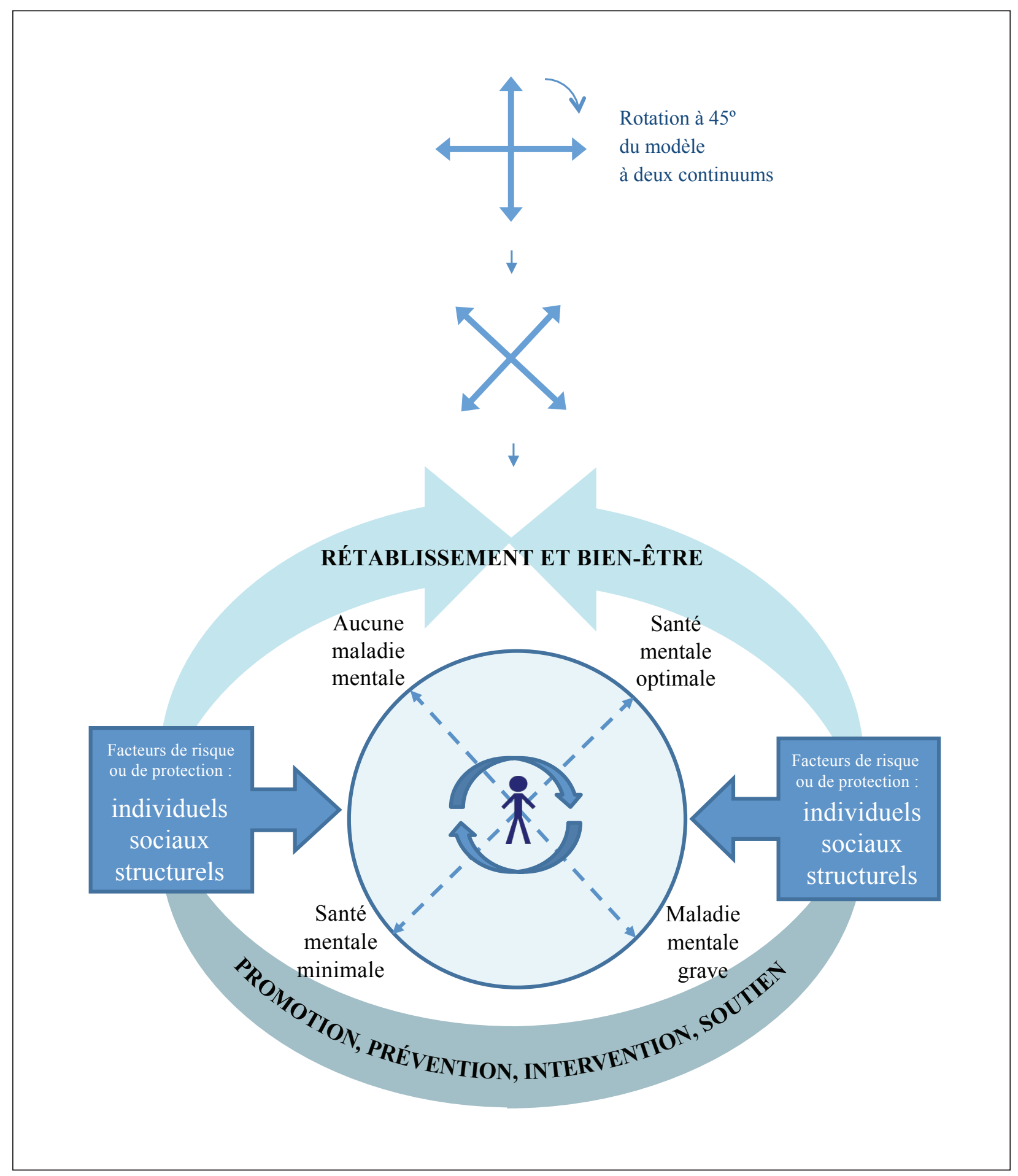




\section{Les principes communs au rétablissement et à la promotion de la santé mentale}

Traditionnellement, les concepts de rétablissement et de promotion de la santé mentale ont également été traités isolément dans la littérature et dans le domaine des politiques publiques. Le concept de rétablissement tire son origine du mouvement social, dont il a été question plus haut, mené par des personnes vivant ou ayant vécu avec un trouble mental ou une maladie mentale (Anthony, 1993 ; Davidson, Harding et Spanoil, 2005 ; Deegan, 1997 ; Jacobson et Greenley, 2001). Le rétablissement est un parcours personnel qui permet à un individu d'arriver graduellement à mener une vie épanouissante, prometteuse et productive malgré les limites que lui impose la maladie (Anthony, 1993). Ce n'est pas un processus qui se fait en retrait du monde : il se construit grâce à des forces individuelles, familiales, sociales et culturelles, et est influencé par un grand nombre de conditions sociales, politiques et économiques (CSMC, 2009).

Or, certains principes de base relatifs au rétablissement et d'autres, relatifs au bien-être, sont à toutes fins pratiques identiques, comme le montre le tableau 1 - par exemple, participer à la vie de la communauté, se réaliser, accomplir un travail productif et fructueux et avoir de la résilience (World Health Organization, 2005b). De plus, comme le rétablissement, la promotion de la santé mentale s'appuie sur des forces liées à des besoins que nous avons tous : mener une vie épanouissante dans la communauté, pouvoir agir sur notre vie, avoir de l'espoir, satisfaire nos besoins essentiels, faire respecter nos droits et entretenir des relations enrichissantes avec nos proches.

Notre modèle rend compte de ces éléments qui sont communs au rétablissement et à la promotion de la santé mentale. Il illustre bien la « trajectoire ascendante » que tous et toutes tentent de parcourir vers le rétablissement et le bien-être, c'est-à-dire soit une diminution de la gravité d'un trouble mental ou d'une maladie mentale, soit une meilleure santé mentale et un plus grand bien-être, et ce, que nous éprouvions ou non les symptômes d'un trouble mental ou d'une maladie mentale. Cette trajectoire, propre à chaque personne, est marquée à certains moments par des contretemps et à d'autres par des progrès. En fait - comme l'illustre notre modèle -, ce qui distingue le rétablissement et le bien-être est plus lié au point de départ de la trajectoire et au soutien qui sera disponible durant le parcours qu'au point d'arrivée qui est visé, puisque ce dernier est le même que l'on parle de rétablissement ou de bien-être, c'est-à-dire mener une vie épanouissante dans la communauté, ce à quoi nous aspirons tous et toutes. De plus, le modèle illustre que le rétablissement peut consister autant en une amélioration de la santé mentale qu'en une réduction des symptôme d'une maladie mentale, et que le chemin qui mène au bien-être est jalonné autant par des améliorations de la santé mentale que par des mesures de prévention de de la maladie.

Enfin, nous plaçons à la base du modèle les ressources liées à la promotion de la santé mentale et à la prévention de la maladie, de même que les interventions et le soutien dont les gens ont besoin - en d'autres mots, tout ce qui peut contribuer au rétablissement et au bien-être -, puisque ces éléments sont littéralement les bases sur lesquelles les gens peuvent s'appuyer tout au long de leur parcours vers le rétablissement et le bien-être. Nous les illustrons également comme faisant partie intégrante du chemin menant au rétablissement et à un plus grand bien-être : elles « enveloppent» la population (le cercle intérieur), signifiant ainsi qu'elles doivent être accessibles à tous les citoyens, au moment où ceux-ci en ont besoin. Les politiques publiques en matière de santé mentale doivent en effet permettre d'offrir aux citoyens le soutien dont ils ont besoin au moment où ils en ont besoin le long de leur parcours; ce soutien doit être constitué d'une combinaison 
Tableau 1

Rétablissement et bien-être : définitions et principes de base

Rétablissement

Définitions

Mener une vie satisfaisante, pleine d'espoir et utile, en dépit des inconvénients causés par les troubles de santé mentale ou la maladie mentale. (CSMC, 2012, p. 16)

Un processus selon lequel les personnes vivant avec des troubles mentaux ou une maladie mentale sont activement engagées et soutenues de manière à ce qu'elles puissent participer activement à leur cheminement vers le bien-être. Le processus de rétablissement s'appuie non seulement sur les forces de la personne, mais aussi sur celles de sa famille, de sa culture et de sa communauté. Il permet à la personne de jouir d'une vie significative au sein de sa communauté et l'aide à atteindre son plein potentiel. (CSMC, 2009, p. 122)
La santé mentale est un état de bien-être dans lequel une personne peut se réaliser, surmonter les tensions normales de la vie, accomplir un travail productif et contribuer à la vie de sa communauté. (World Health Organization, 2004, p. 10)

La promotion de la santé mentale a pour objectif de favoriser la santé mentale en augmentant le bien-être psychologique, les habiletés de vie et la résilience, et en créant des conditions de vie et des environnements de vie constructifs. (Saxena, Jané-Llopis et Hosman, 2006 , p. 6 , n. t.)

Principes de base

- Émancipation

- Droits

- Dignité

- Respect
- Responsabilisation individuelle et collective et renforcement des capacités

- Lutte contre les inégalités
- Autodétermination individuelle

- Choix de services, de soins et de formes de soutien

- Responsabilité

- Capacité d'agir sur notre vie et notre santé
- Développement des capacités d'agir sur notre vie et notre santé

- Promotion de la résilience
- Un logement, un travail et des relations enrichissantes avec des proches

- Une vie épanouissante

- Approche holistique

- Approche axée sur la personne

- Parcours non linéaire

- Enracinement dans le contexte social

- Se construit sur des forces individuelles, familiales, sociales et culturelles
- Tient compte des déterminants sociaux de la santé

- Approche adaptée aux différentes cultures

- Liens entre les différents secteurs

- Collaboration

- Approches ciblées et adaptées à des populations particulières 
de mesures de promotion et de prévention en même temps que d'interventions axées sur le rétablissement, afin de permettre à chaque personne de progresser, à partir de son point de départ, vers le rétablissement et le bien-être. De plus, pour être efficace, ce soutien doit être offert d'une façon qui reflète le changement de paradigme subtil mais essentiel que nous devons opérer pour en arriver, comme nous l'avons expliqué, à une conception de base que l'on pourrait résumer ainsi : en matière de maintien ou d'amélioration de la santé mentale, nous avons tous et toutes les mêmes objectifs, que nous vivions ou non avec un trouble mental ou une maladie mentale.

\section{DISCUSSION}

Nous avons vu plus haut que les idées sont un outil important en matière de changements de troisième ordre (Hall, 1993). Notre modèle conceptuel intégré peut donc, en décrivant le changement de paradigme qui doit fonder les politiques en matière de santé mentale, servir d'outil pour bien faire comprendre la stratégie proposée par la CSMC. Sur ce plan, ce que notre modèle apporte de nouveau, c'est une vision intégrée des concepts liés au rétablissement, à la promotion de la santé mentale et à la prévention de la santé mentale ; cette idée doit contribuer à renverser la conception traditionnelle de la maladie et de la santé mentales pour que, comme le dit le titre de cet article, il n'y ait plus de «nous » et d' " eux ». Notre modèle est donc fondé sur la notion de bien-être de l'ensemble des citoyens : la santé mentale n'est ainsi plus considérée comme une question qui touche uniquement les personnes vivant avec un trouble mental ou une maladie mentale et leurs proches, mais qui touche en fait l'ensemble des la population. Par conséquent, le débat qui entoure les politiques en matière de santé mentale ne concerne plus seulement les ministères de la Santé et les instances responsables de la promotion de la santé mentale: il doit être élargi pour inclure d'autres domaines ou composantes de la société - les services sociaux, le système de justice, le système d'éducation et le monde du travail, de même que les médias et la population en général.

Les commentaires que des décideurs politiques ont fait après avoir lu cet article confirment d'ailleurs que les politiques en matière de santé mentale doivent se fonder sur une approche intégrée. Sans une vision qui traite le phénomène dans sa globalité, il est difficile de susciter l'intérêt des décideurs publics sur des questions de santé mentale, parce que divers intervenants soutiennent chacun de leur côté, auprès de ces décideurs, des questions qui touchent à leur propre domaine d'action (le traitement de la maladie, la promotion de la santé, la nécessité d'interventions précoces, les besoins particuliers de certaines parties de la population, etc.). Les décideurs politiques qui nous ont fait des commentaires étaient tous d'accord sur le fait qu'une vision intégrée ne peut qu'être bénéfique en matière de politiques; et certains ont suggéré qu'il serait possible de rallier tout le monde autour du concept de santé mentale optimale (flourishing, en anglais) ou de celui de vitalité, et un débat plus large est nécessaire sur cette question.

Cela ne signifie aucunement qu'il faille cesser de mettre en place des mesures pour promouvoir spécifiquement soit le rétablissement soit le bien-être : notre modèle suggère plutôt qu'il est essentiel, également, d'élaborer des politiques intégrées qui visent à la fois le rétablissement et le bien-être. De telles politiques s'appuient sur le fait que, si l'on veut, au bénéfice de l'ensemble de la population, favoriser une santé mentale optimale et le bien-être, il faut d'abord combler certains besoins essentiels : un logement, un travail et des relations enrichissantes avec des proches ; un environnement sain dans la communauté, à la maison, à l'école 
et au travail ; et l'accès à des services, à des soins et à du soutien, offerts de façon coordonnée et au moment où les gens en ont besoin. La possibilité de concevoir des politiques intégrées existe à plusieurs niveaux (voir le tableau 2), par exemple : agir au niveau des déterminants sociaux de la santé, faire de l'éducation sur la santé mentale et la maladie mentale, assurer la formation du personnel des services sociaux et de santé, revoir la façon dont les services sont offerts en général.

Tableau 2

Concevoir des politiques intégrées : quelques exemples à différents niveaux

\begin{tabular}{|c|c|}
\hline Niveaux & Exemples \\
\hline $\begin{array}{l}\text { Déterminants sociaux } \\
\text { de la santé }\end{array}$ & $\begin{array}{l}\text { Adopter des mesures touchant le logement, l'éducation, le revenu et l'emploi } \\
\text { qui peuvent aussi contribuer à accroître le bien-être, à prévenir la maladie } \\
\text { mentale et à favoriser le rétablissement. }\end{array}$ \\
\hline Sensibilisation et éducation & $\begin{array}{l}\text { Offrir de l'information autant sur la santé que sur la maladie mentales, grâce à } \\
\text { des campagnes publiques d'information, à de la formation sur la santé mentale } \\
\text { et à des modules d'enseignement dans les écoles, les collèges et les universités } \\
\text { ainsi que dans les milieux de travail. }\end{array}$ \\
\hline $\begin{array}{l}\text { Formation et développement } \\
\text { du personnel }\end{array}$ & $\begin{array}{l}\text { Offrir aux professionnels en poste des programmes de développement des } \\
\text { compétences et de la formation continue; créer, dans les collèges et les } \\
\text { universités, des programmes de formation qui mettent l'accent sur les principes } \\
\text { communs aux notions de rétablissement et de bien-être. }\end{array}$ \\
\hline $\begin{array}{l}\text { Programmes interministériels } \\
\text { d'apprentissage et d'échanges }\end{array}$ & $\begin{array}{l}\text { Offrir, à des représentants de divers ministères et organismes gouvernementaux, } \\
\text { des ateliers qui portent sur la promotion de la santé afin de déterminer des } \\
\text { domaines d'action où il est possible d'élaborer des programmes communs. }\end{array}$ \\
\hline Réallocation de fonds & $\begin{array}{l}\text { En plus d'une augmentation du financement global, réallouer des fonds et } \\
\text { des ressources existants pour mettre l'accent sur la promotion, la prévention, } \\
\text { l'intervention et le soutien, tel que l'indique notre modèle intégré. }\end{array}$ \\
\hline $\begin{array}{l}\text { Prestation des services } \\
\text { et des soins }\end{array}$ & $\begin{array}{l}\text { Dans les évaluations, les soins de première ligne et les soins, intégrer des } \\
\text { interventions dont l'efficacité a été démontrée et qui contribuent autant à } \\
\text { améliorer le bien-être qu'à réduire les symptômes de la maladie ; cette approche } \\
\text { peut être utilisée autant en santé physique qu'en santé mentale. }\end{array}$ \\
\hline $\begin{array}{l}\text { Approches visant l'ensemble } \\
\text { des périodes de la vie }\end{array}$ & $\begin{array}{l}\text { Mettre en place des programmes de santé mentale qui touchent les soins } \\
\text { prénataux, la petite enfance, les enfants en milieu scolaire, les milieux de } \\
\text { travail, les personnes âgées et les communautés dans leur ensemble. }\end{array}$ \\
\hline
\end{tabular}


Par ailleurs, comme l'affirme la CSMC, une approche intégrée des politiques en matière de santé mentale nécessiterait à la fois de réaffecter une partie des ressources actuelles en promotion, en prévention, en intervention et en soutien et d'investir de nouvelles sommes à tous les niveaux (CSMC, 2012, p. 126). De plus (comme l'ont déjà fait les États-Unis : voir l'exemple donné par Weiss, 1990, cité plus haut), l'allocation de subventions et de bourses de recherche ciblées pourrait contribuer à l'élaboration et à l'adoption d'approches véritablement intégrées. De la formation conjointe pour le nouveau personnel de même que le développement des compétences pour le personnel déjà en place, sur des thèmes liés aux approches stratégiques en rétablissement et en bien-être, au niveau théorique et clinique, permettraient également de diffuser plus largement les nouvelles approches. D'autres types d'activités, simples et peu coûteuses, pourraient aussi être encouragées - des journaux de gratitude et des gestes de gentillesse, par exemple -, dans l'ensemble de la population, puisque la recherche en psychologie positive a montré que même de petites choses peuvent améliorer de façon réelle et immédiate le bien-être (Seligman et al., 2005).

Sur le plan du parcours de vie, une approche intégrée en santé mentale signifie la mise sur pied de programmes prénataux et conçus pour la petite enfance : ce sont deux façons de promouvoir la santé mentale des mères et des enfants, qui permettent aussi de diagnostiquer très tôt des problèmes de santé mentale et d'offrir si nécessaire des soins axés sur le rétablissement. Il faut ensuite, dans le cadre scolaire, permettre des apprentissages socio-affectifs, favoriser la résilience et offrir des interventions et du soutien en temps opportun pour répondre aux besoins des enfants. Par ailleurs, dans les milieux de travail, on doit améliorer les connaissances en matière de santé mentale, encourager les échanges, soutenir l'ensemble des employés et favoriser certains accommodements pour répondre à des besoins particuliers. Toutes ces mesures contribueraient à l'édification de collectivités plus conviviales et plus inclusives, formées de citoyens en meilleure santé mentale, et capables de répondre aux besoin de tous et de toutes, à tous les moments de leur vie, qu'ils vivent ou non avec un trouble mental ou une maladie mentale et quel que soit leur état de santé mentale.

Il est par ailleurs essentiel d'évaluer de façon rigoureuse toutes les mesures mises en place. Il existe déjà des outils à cet effet : en Écosse, par exemple, on recueille des données basées sur un ensemble d'indicateurs qui permettent d'évaluer la santé mentale grâce à des mesures liées autant à la santé qu'à la maladie mentales ainsi qu'à une gamme de facteurs individuels, sociaux et structurels qui influencent à la fois le rétablissement et le bien-être (Catto, 2012). Ce sont d'excellents moyens de mesurer l'efficacité d'approches intégrées adoptées dans le cadre de politiques en matière de santé mentale. Le Canada a d'ailleurs commencé ce type de démarches, avec l'ajout de mesures de santé mentale au contenu de l'Enquête annuelle sur la santé dans les collectivités canadiennes de Statistique Canada (Statistics Canada, 2012).

Notre modèle a par ailleurs des implications sur le plan de la recherche en politiques en matière de santé mentale ; des études plus poussées sur le bien-être, la santé mentale et le rétablissement sont par exemple nécessaires (Provencher et Keyes, 2011 ; Slade, Adams et O’Hagan, 2012). Provencher et Keyes (2011) ont déjà défini, dans un effort pour encourager la recherche sur les questions du rétablissement, six états de rétablissement liés au modèle à deux continuums : la « guérison complète d'une maladie mentale » y correspond à la fois à une santé mentale optimale (ou « florissante ») et à la disparition totale des symptômes. Des chercheurs pourraient par exemple comparer les effets des soins offerts selon les modèles traditionnels aux personnes vivant avec une maladie mentale et les effets des soins qui intègrent des activités qui font la 
promotion de la santé mentale et qui comportent des éléments inspirés de la psychologie positive. D'autres pourraient évaluer les impacts de mesures anti-stigmatisation et de promotion de la santé mentale qui comportent de l'information sur le rétablissement et le bien-être en comparaison avec des approches traditionnelles.

Il est toutefois important de reconnaître que la recherche de ce type comporte des limites. Notre modèle s'appuie sur des conceptions de base généralement reconnues dans la littérature universitaire, et il répond à la nécessité d'une approche unifiée tel que le reconnaissent des informateurs importants, mais, à ce jour, il n'a été validé que par un échantillon de commodité de chercheurs et de décideurs publics. Même si ces intervenants viennent de divers domaines et travaillent à plusieurs niveaux de gouvernements, notre modèle gagnerait à être validé par un plus grand nombre de décideurs. De plus, les différences importantes (et étonnantes) que l'évaluation, faite grâce au modèle à deux continuums, a permis d'établir de la proportion de la population qui est en très bonne santé mentale au Canada et aux États-Unis (voir plus haut) exigent des recherches plus poussées (Gilmour, 2014).

Nous présentons donc notre modèle pour qu'il soit examiné de plus près et débattu. Il peut, selon nous, servir de cadre conceptuel cohérent dans la mise en place des recommandations de la stratégie de la CSMC. Il peut aussi être utile pour permettre de définir les objectifs politiques nécessaires pour que, comme l'ont souligné nos informateurs, l'ensemble des décideurs publics se penchent sérieusement sur la question de la santé mentale et passent à l'action de façon concertée. Comme nous l'avons précisé plus haut, le débat public joue un rôle majeur quand il est question de changements de troisième ordre (Hall 1993); nous espérons donc que notre modèle suscitera de nombreuses réactions, et que plusieurs personnes contribueront à le raffiner et à proposer des façons de l'appliquer.

\section{CONCLUSION}

Les idées peuvent constituer un levier important dans la transformation des politiques publiques et de la prestation des soins en santé mentale : c'est ce qu'indiquent la revue de la littérature sur ce sujet ainsi que le survol de l'évolution des politiques en matière de santé mentale que nous avons présentés au début de cet article. Le modèle conceptuel intégré que nous offrons peut ainsi non seulement servir d'outil aux décideurs publics et aux prestataires de soins pour appliquer la stratégie proposée par la CSMC, mais également guider plus largement le travail à faire pour transformer les systèmes de santé mentale et les services sociaux et de santé partout au Canada. Notre modèle fournit la base sur laquelle doit s'appuyer cette transformation, en éliminant les distinctions conceptuelles qui ont traditionnellement isolé du reste de la population les personnes vivant avec un trouble mental ou une maladie mentale. Notre modèle montre que la promotion de la santé mentale fait partie intégrante du rétablissement en matière de maladie mentale, et qu'il faut agir sur les facteurs individuels, sociaux et structurels qui influencent à la fois le rétablissement et la santé mentale. Une véritable intégration de ces notions peut contribuer à changer les idées encore très présentes sur ce que sont la santé mentale et la maladie mentale; et, avec le temps, les effets combinés de la normalisation et de l'intégration permettront de faire disparaître la stigmatisation des personnes vivant avec un trouble mental ou une maladie mentale. Nous souhaitons que les lecteurs examinent notre modèle, et qu'ils proposent des façons de l'améliorer tout autant que de l'appliquer à l'élaboration et à l'utilisation d'approches intégrées au Canada et ailleurs dans le monde. 


\section{NOTE}

1. En accord avec ce que les auteurs de Changer les orientations - Stratégie en matière de santé mentale pour le Canada ont choisi de faire, nous utilisons dans cet article les termes « trouble mental » et « maladie mentale » afin de refléter l'ensemble des points de vue présents dans la controverse qui entoure la terminologie dans ce domaine (CSMC, 2012, p. 14).

\section{RÉFÉRENCES}

Anthony, W. 1993. « Recovery from mental illness: The guiding vision of the mental health service system in the 1990s », Psychosocial Rehabilitation Journal, vol. 16, p. 11-23.

Ascentum. 2009. Setting the goals for a mental health strategy for Canada. Préparé pour la Commission de la santé mentale du Canada. Récupéré en ligne le 28 mai 2015 : http:/www.mentalhealthcommission.ca/English/system/ files/private/Diversity_Consultation_Report_Ch1-3_ENG_0.pdf

Bartram, M. 2012. Mental Health Strategy for Canada. Affiche présentée à la Chronic Disease Prevention Alliance of Canada Annual Conference, Ottawa, Ontario.

Béland, D. 2009. «Ideas, institutions and policy change », Journal of European Public Policy, vol. 16, n 5, p. 701-718.

Canadian Institute for Health Information. 2011. Recognizing and exploring positive mental health—policy dialogue: Synthesis and analysis. Ottawa, Ontario.

Catto, S. 2012. Scotland's mental health: Adults 2012 briefing paper. Édimbourg : NHS Health Scotland.

Commonwealth of Australia. 2009. Fourth national mental health plan: An agenda for collaborative government action in mental health 2009-2014. Barton, Territoire de la capitale australienne.

Corrigan, P., et F. Miller. 2004. « Shame, blame, and contamination: A review of the impact of mental illness stigma on family members », Journal of Mental Health, vol. 13, n 6, p. 537-548.

CSMC (Commission de la santé mentale du Canada). 2009. Vers le rétablissement et le bien-être-Cadre pour une stratégie en matière de santé mentale au Canada. Calgary, Alberta.

CSMC (Commission de la santé mentale du Canada). 2012. Changer les orientations, changer des vies - Stratégie en matière de santé mentale pour le Canada. Calgary, Alberta.

Davidson, L., Harding, C., et L. Spanoil. 2005. Recovery from severe mental illnesses: Research evidence and implications for practice. Boston, Massachusetts : Boston University.

Deegan, P. 1997. « Recovery and empowerment for people with psychiatric disabilities », Social Work in Health Care, vol. $25, \mathrm{n}^{\circ} 3$, p. 11-24.

Doern, G. B., et R. W. Phidd. 1983. Canadian public policy: Ideas, structure, process. Toronto, Ontario : Methuen.

European Union. 2008. European pact for mental health and well-being. Bruxelles.

Foresight Mental Capital and Wellbeing Project. 2008. Final project report. Londres : The Government Office for Science.

Freeze, F., et W. Walker Davis. 1997. " The consumer-survivor movement, recovery, and consumer professionals », Professional Psychology: Research and Practice, vol. 28, nº 3, p. 243-245.

Friedli, L., et M. Parsonage. 2009. Promoting mental health and preventing mental illness: The economic case for investment in Wales. Cardiff : All Wales Mental Health Promotion Network.

Gilmour. 2014. " Positive mental health and mental illness », Health Reports (vol. 82-003-x). Ottawa, Ontario : Statistics Canada.

Government of Canada. 2006. The human face of mental health and mental illness in Canada. Ottawa, Ontario.

Hall, P. 1993. " Policy paradigms, social learning and the state: The case of economic policymaking in Britain », Comparative Politics, vol. 25, no 3, p. 275-296.

Hand, L. 2012. Public policy design and assumptions about human behavior. Préparé pour la 2012 Western Political Science Association Annual Conference. Récupéré en ligne : http://wpsa.research.pdx.edu/meet/2012/handlaura.pdf

Health and Welfare Canada. 1986. Ottawa charter for health promotion. Ottawa, Ontario.

Health and Welfare Canada. 1988. Mental health for Canadians: Striking a balance. Ottawa, Ontario.

Her Majesties' Government. 2010. No health without mental health: A cross-government mental health strategy for people of all ages. Londres. 
Houston, D., et L. Richardson. 2000. «The politics of air bag safety: A competition among problem definitions », Policy Studies Journal, vol. 28, n 3, p. 585-501.

Howlett, M. 1991. « Policy instruments, policy styles, and policy implementation: National approaches to theories of instrument choice », Policy Studies Journal, vol. 19, n 2, p. 1-21.

Howlett, M. 2000. « Managing the "hollow state": Procedural policy instruments and modern governance as various functions and activities », Canadian Public Administration, vol. 43, n 4, p. 412-431.

Howlett, M., Kim, J., et P. Weaver. 2005. «Assessing instrument mixes: Methodological issues in contemporary implementation research ». Récupéré en ligne le 12 août 2014 : http://www.cpsa-acsp.ca/papers-2005/Howlett.pdf.

Jacobson, N., et D. Greenley. 2001. « What is recovery? A conceptual model and explication », Psychiatric Services, vol. $52, n^{\circ} 4$, p. $482-485$.

Jacobson N., et L. Curtis. 2000. « Recovery as policy in mental health services: Strategies emerging from the States », Psychosocial Rehabilitation Journal, vol. 23, nº 4, p. 333-341.

Jordan, A., Rudiger, W., Zito, A., et L. Bruckner. 2003. « European governance and the transfer of 'new' environmental policy instruments (NEPIs) in the European Union », Public Administration Review, vol. 81, no 3, p. 555-574.

Keyes, C. 2002. «The mental health continuum: From languishing to flourishing in life », Journal of Health and Social Behavior, vol. 43, n 2, p. 207-222.

Kingdon, J. W. 1995. Agendas, alternatives and public policies ( $2^{e}$ éd.). New York : Longman.

Kirby, M. J., et W. J. Keon. 2004. Mental health policies and programs in selected countries: Report 2. Ottawa, Ontario : The Standing Senate Committee on Social Affairs, Science and Technology.

Kirby, M. J., et W. J. Keon. 2006. Out of the shadows at last: Transforming mental health, mental illness and addiction services in Canada. Ottawa, Ontario : The Standing Senate Committee on Social Affairs, Science and Technology.

MacNaughton, E., Nelson, G., et P. Goering. 2013. « Bringing politics and evidence together: Policy entrepreneurship and the conception of the At Home/Chez Soi initiative for addressing homelessness and mental illness in Canada », Social Science \& Medicine, vol. 82, p. 100-107.

Minister of Health. 2005. Te Tāhuhu: Improving mental health 2005-2015: The second New Zealand mental health and addiction plan. Wellington, Nouvelle-Zélande.

Mulvale, G. 2012. «The meaning of recovery for policy-making ». Présenté à la Conférence nationale sur le leadership en santé, Ottawa, Ontario.

Mulvale, G., Abelson, J., et P. Goering. 2007. « Mental health service delivery in Ontario, Canada: How do policy legacies shape prospects for reform? », Health Economics, Policy and Law, vol. 2, n 4, p. 363-389.

Mulvale, G., et M. Bartram. 2009a. An integrated model of recovery and well-being. Affiche présentée à la conférence Into the Light de la CSMC, Vancouver, Colombie-Britannique.

Mulvale, G., et M. Bartram. 2009b. «Recovery in the Canadian context: Feedback on the framework for mental health strategy development », Canadian Journal of Community Mental Health, vol. 28, nº 2, p. 7-15.

Mulvale, G., Chodos, H., Bartram, M., MacKinnon, M.-P., et M. Abud. 2014. «Engaging civil society through deliberative dialogue to create the first Mental Health Strategy for Canada: Changing Directions, Changing Lives », Social Science \& Medicine, vol. 123, p. 262-268.

Pan-Canadian Planning Committee for Mental Health Promotion and Mental Illness Prevention. 2009. « Toward flourishing for all: National mental health promotion and mental illness prevention policy for Canadians ». Récupéré en ligne le 18 octobre 2014 : http://sites.utoronto.ca/chp/mentalhealthpdffinal/Toward Flourishing for All Policy Recommendations Final April.pdf

President's New Freedom Commission on Mental Health. 2003. «Achieving the promise: Transforming mental health care in America ». Récupéré en ligne le 27 mai 2015 : http:/govinfo.library.unt.edu/mentalhealthcommission/ reports/FinalReport/downloads/FinalReport.pdf

Provencher, H., et C. Keyes. 2011. «Complete mental health recovery: Bridging mental illness with positive mental health », Journal of Public Mental Health, vol. 10, nº 1, p. 57-69.

Public Health Agency of Canada. 2013. "What makes Canadians healthy or unhealthy? ». Récupéré en ligne le 19 octobre 2014 : http://www.phac-aspc.gc.ca/ph-sp/determinants/determinants-eng.php

Rothman, D. 1990. The discovery of the asylum: Social order and disorder in the new republic. New York : Aldine de Gruyter. 
Rüsch, N., et P. Corrigan. 2005. « Mental illness stigma: Concepts, consequences, and initiatives to reduce stigma », European Psychiatry, vol. 20, nº 8, p. 529-539.

Saxena, S., Jané-Llopis, J., et C. Hosman. 2006. « Prevention of mental and behavioural disorders: Implications for policy and practice », World Psychiatry, vol. 5, n 1, p. 5-14.

Schmidt, V. 2010. «Taking ideas and discourse seriously: Explaining change through discursive institutionalism as the fourth 'new institutionalism' », European Political Science Review, vol. 2, nº 1, p. 1-25.

Scott, A., et W. Lynere. 2011. « Valued identities and deficit identities: Wellness recovery action planning and selfmanagment in mental health », Nursing Inquiry, vol. 18, nº 1, p. 40-49.

Scottish Government. 2007. Towards a mentally flourishing Scotland: The future of mental health improvement in Scotland 2008-11. Édimbourg.

Seddoh, A., et S. Akortey Akor. 2012. « Policy initiation and political levers in health policy: Lessons from Ghana's health insurance », BMC Public Health, vol. 12, nº S1, p. S10.

Seligman, M., Steen, A., Nansook Park, N., et C. Peterson. 2005. « Positive psychology progress - empirical validation of interventions ", American Psychologist, vol. 60, n ${ }^{\circ}$ 5, p. 410-421.

Shepherd, G., Boardman, J., et M. Slade. 2008. Making recovery a reality. Londres : Sainsbury Centre for Mental Health.

Simmons, H. 1989. Unbalanced: Mental health policy in Ontario, 1930-1988. Toronto : Wall \& Thompson.

Slade, M., Adams, N., et M. O’Hagan. 2012. « Recovery: Past progress and future challenges », International Review of Psychiatry, vol. 24, no 1, p. 1-4.

Spillane, J., Reiser, B., et T. Reimer. 2002. « Policy implementation and cognition: Reframing and refocusing implementation research », Review of Educational Research, vol. 27, n 3, p. 387-431.

Statistics Canada. 2012. Canadian Community Health Survey: Annual Component. Récupéré en ligne le 29 novembre $2014:$ http://www23.statcan.gc.ca/imdb/p2SV.pl?Function=getSurvey\&SDDS=3226

Stuart, H., Arboleda-Florez, J., et N. Sartorius. 2012. Paradigms lost: Fighting stigma and the lessons learned. New York : Oxford University Press.

Tsankova, N., Renthal, W., Kumar, A., et E. Nestler. 2007. « Epigenetic regulation in psychiatric disorders », Nature Reviews Neuroscience, vol. 8, p. 355-367.

UK Department of Health. 2004. The ten essential capabilities: A framework for the whole of the mental health workforce. Londres.

Walt, G., Shiffman, J., Schneider, H., Murray, S., Brugha, R., et L. Gilson. 2008. «'Doing' health policy analysis: Methodological and conceptual reflections and challenges », Health Policy and Planning, vol. 23, p. 308-317.

Weiss, J. 1990. «Ideas and inducements in mental health policy », Journal of Policy Analysis and Management, vol. 9, $\mathrm{n}^{\circ}$ 2, p. 178-190.

Weisser, J., Morrow, M., et B. Jamer. 2011. A critical exploration of social inequities in the mental health recovery literature. Vancouver, Colombie-Britannique : Centre for the Study of Gender, Social Inequities and Mental Health.

World Health Organization. 2004. Promoting mental health. Genève. Traduction française : Aide-mémoire 220 de l'OMS, août 2014, récupéré en ligne : http://www.who.int/mediacentre/factsheets/fs220/fr/

World Health Organization. 2005a. Prevention of mental disorders: Effective interventions and policy options. Genève. World Health Organization. 2005b. Promoting mental health: Concepts, emerging evidence, practice. Genève.

Wright, D. 2004. «The politics of mental health in Ontario: From asylum to integration ». Présenté à la Shared Citizenship Public Lecture Series, University de Toronto, Toronto, Ontario. 